ŠImUn Novaković

UDK: 811.163.42'271.1

Izvorni znanstveni članak

Primljen 11. X. 2019.

Filozofski fakultet Sveučilišta u Mostaru

simun.novakovic@ff.sum.ba

\title{
IZVANPARTIJSKE REAKCIJE I RASPRAVE 0 DEKLARACIJI O NAZIVU I POLOŽAJU HRVATSKOG KNJIŽEVNOG JEZIKA PREMA PISANJU POLITIKE I BORBE
}

\section{Sažetak}

Nakon pojave Deklaracije o nazivu i položaju hrvatskog književnog jezi$k a$ uslijedile se rasprave, a potom i osude potpisnika navedene inicijative. Pored osuda koje su dolazile iz gradskih, republičkih i saveznih partijskih središta, osudama su se pridružila i različita hrvatska republička i jugoslavenska savezna tijela. Srbijanske su tiskovine opširno izvještavale sa sjednica Republičkoga, Privrednoga, Socijalno-zdravstvenoga, Organizaciono-političkoga i Prosvjetno-kulturnoga vijeća Sabora SR Hrvatske te Prosvjetno-kulturnoga, Privrednoga, Socijalno-zdravstvenoga i Saveznoga vijeća Savezne skupštine. O Deklaraciji su raspravljala i neka druga republička i savezna tijela, i to Republička privredna komora Hrvatske, Savjet za naučni rad Hrvatske, Odbor Saveznoga vijeća za društveno-ekonomske odnose i Centralno vijeće Saveza sindikata Jugoslavije. O Deklaraciji su se očitovala i neka izvanpartijska tijela u $\mathrm{BiH}$. Riječ je o nastavnicima Filozofskoga fakulteta u Sarajevu i Upravnome odboru i Predsjedništvu Udruženja univerzitetskih nastavnika i naučnih radnika BiH. Srbijanske su tiskovine davale dosta medijskoga prostora i pojedinačnim reakcijama pojedinaca i neformalnih grupa. Oni su se o Deklaraciji uglavnom očitovali otvorenim pismima. Ocjene su Deklaracije, svih gore navedenih tijela i pojedinaca, na tragu partijskih stavova. Proglašavaju je atakom na bratstvo i jedinstvo, brane jedinstvo hrvatsko- 
ga i srpskoga jezika, pozivaju na utvrđivanje odgovornosti potpisnika. Zbog uključenosti u donošenje Deklaracije neki su potpisnici podnijeli ostavke na dužnosti i kandidacijske liste za pojedina republička i savezna vijeća.

Ključne riječi: Deklaracija o nazivu i položaju hrvatskog književnog jezi$k a$; hrvatska saborska i jugoslavenska savezna vijeća; ideološke rasprave o jeziku; reakcije pojedinaca i neformalnih grupa; kažnjavanje potpisnika Deklaracije

\section{Uvod}

U rano proljeće 1967. godine osamnaest je hrvatskih kulturnih institucija, u tijeku rasprava o promjeni Ustava SFRJ, nadležnim republičkim saborskim i saveznim skupštinskim organima dostavilo amandmane za izmjenu ustavnih odredbi o nazivu i uporabi jezika naroda Jugoslavije. Dva dana nakon što je spomenuta inicijativa 17. ožujka 1967. godine objavljena u zagrebačkom Telegramu pod naslovom Deklaracija o nazivu i položaju hrvatskog književnog jezika, na skupštini je Udruženja književnika Srbije usvojen Predlog za razmišljanje. ${ }^{1}$ Medijske su kuće odmah, očito po naputku tadašnjih partijskih organa, ${ }^{2}$ počele negativno

1 U Predlogu se, između ostaloga, navodi da grupa pisaca smatra „legitimnim i neotuđivim pravom svakoga naroda da donosi Odluke o nazivu i razvoju svoga sopstvenog jezika“. „Šta sadrži Predlog za razmišljanje“, Borba, god. xxxiı., br. 89., 2. travnja 1967., str. 5. Dalje se navodi da se Deklaracija smatra reprezentativnom i meritornom jer su ju donijele institucije koje su najmjerodavnije za pitanje hrvatskoga jezika te da se Bečki i Novosadski dogovori smatraju poništenim. Budući da je Ustavom zagarantirano pravo na samostalan razvitak nacionalnoga jezika i kulture, potpisnici Predloga traže da se afirmacija samostalnosti naziva i razvoja hrvatskoga i srpskoga jezika osigura ustavnim propisima. Stoga su potpisnici namjeravali poslati zahtjev Skupštini Srbije, Saboru Hrvatske i Saveznoj skupštini „da se ubuduće dosledno i obavezno izbace iz zvanične upotrebe nazivi hrvatsko-srpski i srpsko-hrvatski“. Isto. Također "grupa pisaca zahteva da se u Ustav SR Srbije i SR Hrvatske unesu propisi koji obezbeđuju svim Hrvatima i Srbima pravo na školovanje na svom jeziku i pismu i po svojim nacionalnim programima." Isto. Navedeno se pravo treba osigurati svim Hrvatima koji žive u SR Srbiji i Srbima koji žive u SR Hrvatskoj. Predlog se dotaknuo i uporabe pisma, s prijedlogom da RTB prestane neovlašteno igrati „ulogu centralnog jugoslovenskog studija, i da u svom lokalnom programu uvede ćirilicu, a da se u zajedničkim emisijama RT Jugoslavije paralelno upotrebljavaju oba pisma“. Isto.

$2 \quad$ Samo dan nakon objavljivanja Deklaracije sastao se dio članova Izvršnoga komiteta i Predsjedništva Centralnoga komiteta Saveza komunista Hrvatske s Ivom Bojanićem, direktorom RTV Zagreba i Božidarom Novakom, direktorom Vjesnika. Tom je prigodom dogovoreno 
izvještavati o Deklaraciji. U više su navrata zasjedali Gradski komitet Saveza komunista Zagreba i osnovne organizacije Saveza komunista institucija potpisnica Deklaracije, a o Deklaraciji se očitovao i CK SK Hrvatske. Na navedenim je partijskim forumima osuđena i označena kao akt nacionalističkoga i šovinističkoga karaktera koji ruši bratstvo i jedinstvo naroda Jugoslavije, a potpisnicima su izrečene različite stegovne mjere, među kojima i izbacivanje iz Saveza komunista.

O Deklaraciji se počelo pisati već u osvit demokratskih promjena, posebno u Vjesniku. ${ }^{3}$ Matičino Kolo (2009.) i Hrvatska revija (2017.) tematski su posvećeni Deklaraciji. ${ }^{4}$ Novi doprinos o ovoj problematici,

da Radio-televizija Zagreb i Vjesnik objave političke komentare u kojima bi se osudio način kako je pripremana Deklaracija. Usp. Jozo IvičEvić-BAKULIć, „Deklaracija o nazivu i položaju hrvatskog književnog jezika u sklopu suvremene hrvatske povijesti“, Kolo, br. 1. - 2., 2009., <http://www.matica.hr/kolo/314/deklaracija-o-nazivu-i-polozaju-hrvatskoga-knjizevnog-jezika-u-sklopu-suvremene-hrvatske-povijesti-20691/>, (20. I. 2019.); MARKO SAMARDŽIJA, „Pola stoljeća od donošenja Deklaracije o nazivu i položaju hrvatskog književnog jezika", Mostariensia, Mostar, god. xxi. (2017.) br. 2., str. 12.

3 Vidi „Dokumenti, sjećanja 1991-1993.", Deklaracija o nazivu i položaju hrvatskog književnog jezika: građa za povijest Deklaracije, pripremila Jelena Hekman, Matica hrvatska, Zagreb, 1997., str. 83-203. Vjesnik je bio i jedan od glavnih protagonista osude Deklaracije nakon njezina pojavljivanja. Člankom „Politika, a ne lingvistika“ te člancima Miloša Žanka započela je medijska hajka protiv potpisnika Deklaracije. Riječ je o člancima: „O različitim putevima i metodama rješavanja nacionalnog pitanja i mađunacionalnih odnosa“, „Sporna pitanja ne rješavaju se političkom demonstracijom" $i$,Zatvaranje je znak slabosti, a ne snage jedne kulture“. Dijelove su navedenih rasprava preuzele i srbijanske tiskovine, i to: „Dr Miloš Žanko: Pogreške i zablude skupo se plaćaju“, Politika, god. LXIv., br. 19201., 20. ožujka 1967., str. 6.; „Ne radi se o izmeni naziva već o novoj tezi u pitanju dosad zajedničkog književnog jezika“, Politika, god. LXIV., br. 19202., 21. ožujka 1967., str. 6. i „Uz nacionalno pitanje vezani su porazi i najveći trijumf radničke klase i SKJ“, Politika, god. LXIV., br. 19203., 22. ožujka 1967., str. 6. Iako Borba u svome izdanje od 21. ožujka 1967. godine navodi da su u jučerašnjem broju objavili prvi dio Žankove rasprave, spomenuti članak u navedenom broju nismo pronašli. Izgleda da su u Borbi objavljene samo dvije posljednje Žankove rasprave, i to: „Sporna pitanja ne rešavaju se političkom demonstracijom", Borba, god. XXXII., br. 77., 21. ožujka 1967., str. 4. i „Zatvorenost je dokaz slabosti, a ne jakosti jedne kulture“, Borba, god. XXXII., br. 78., 22. ožujka 1967., str. 4 .

4 U Kolu su objavljeni članci Radoslava Katičića „Deklaracija i jezikoslovlje“, Milana Moguša „Značenje Deklaracije u povijesti hrvatskog jezika“, Dalibora Brozovića „O nekima manje spominjanim jezikoslovnim aspektima Deklaracije o nazivu i položaju hrvatskoga književnog jezika“, Stjepana Babića „O Deklaraciji - činjenice i pretpostavke“, Dubravka Jelčića „O Deklaraciji (Sjećanja)“, Josipa Lisca „Deklaracija i njeni sastavljači: Tko je bio sedmi?“, Branka Kune „Značenje Deklaracije danas“, Branimira Belaja „Nekoliko napomena o zadacima jezikoslovne kroatistike danas“, Joze Ivičevića-Bakulića „Deklaracija o nazivu i položaju 
pogotovu u kontekstu pisanja ondašnjih tiskovina, predstavlja knjiga vijesti, komentara, osuda i zaključaka o Deklaraciji, koju je priredio Marko Samardžija, a objavila Matica hrvatska 2017. godine. ${ }^{5}$ U navedenoj se knjizi nalazi i pogovor koji sažeto prikazuje okolnosti koje su prethodile donošenju Deklaracije. O Deklaraciji je nedavno pisano i u kontekstu reakcija komunističkih partijskih tijela prema izvještavanju nekih srbijanskih tiskovina. ${ }^{6}$

Rasprave i osude Deklaracije nadišle su unutarpartijske krugove jer je o njoj raspravljao širok spektar različitih institucija, pa i pojedinaca. Budući da je Deklaracija bila dostavljena Saboru SR Hrvatske i Saveznoj skupštini, o njoj su posebno raspravljala saborska i savezna skupštinska vijeća. U raspravama i osudama sudjelovala su neka druga tijela, pa čak

hrvatskoga književnog jezika u sklopu suvremene hrvatske povijesti“, Ljubomira Antića „Hrvatski komunisti i nacionalni identitet“, Josipa Šentije „Jezik i jezična politika u medijima uoči Deklaracije“, Josipa Pavičića „Deklaracija o jeziku samostalnosti“, Ivana Čizmića „Deklaracija o nazivu i položaju hrvatskoga književnog jezika i njezin odjek u hrvatskoj političkoj emigraciji“, Mate Kapovića „Položaj hrvatskoga jezika u svijetu danas“, Mirka Petija „Jezik kojim je pisana Deklaracija“. Vidi Kolo, Matica hrvatska, Zagreb, br. 1. - 2., 2009. U Hrvatskoj reviji nalaze se članci Radoslava Katičića „Sjećanja na dane nastajanja Deklaracije o nazivu i položaju hrvatskog književnog jezika“, Augusta Kovačeca „Deklaracija o nazivu i položaju hrvatskoga jezika u povijesnom kontekstu“, Josipa Lisca „Deklaracija i Dalibor Brozović“ i Vinka Grubišića „Pogledi na Deklaraciju o nazivu i položaju hrvatskog književnog jezika u Sjevernoj i Južnoj Americi“. Vidi Hrvatska revija, Matica hrvatska, Zagreb, br. 1., 2017.

5 Marko Samardžija je u navedenoj knjizi objavio Vjesnikove članke, koje su preuzele i srbijanske tiskovine. Riječ je o člancima "Politika, a ne lingvistika“ (Deklaracija o nazivu i položaju hrvatskog književnog jezika 1967. - 1917.: vijesti, komentari, osude i zaključci, Matica hrvatska, Zagreb, 1917., str. 24. - 28.), „O različitim putevima i metodama rješavanja nacionalnog pitanja i međunacionalnih odnosa“ (Isto, str. 38. - 45.), „Sporna pitanja ne rješavaju se političkom demonstracijom“ (Isto, str. 46. - 57.) i „Zatvaranje je znak slabosti, a ne snage jedne kulture" (Isto, str. 58. - 66.). Objavio je i neke članke koji su izravno preuzeti iz srbijanskih tiskovina. Najviše je članaka preuzeo iz Borbe, a riječ je o člancima „Šta sadrži 'Predlog za razmišljanje"“ (Isto, str. 30. - 33.), "Juriš na otvorena vrata“ (Isto, str. 34. - 37.), „Podzemne inicijative“ (Isto, str. 73. - 75.), „Kuda idemo?“ (Isto, str. 79. - 85.), „U JNA nikome ne smeta sadašnja jezička praksa“ (Isto, str. 151. - 153.), „Jednodušnost“ (Isto, str. 156. - 158.), „Žaljenja“ i „objašnjenje“ (Isto, str. 176. - 178.) i „Manifestacija snage i jedinstva“ (Isto, str. 249. - 251.). Daleko je manje preuzetih članka iz Politike, a riječ je o člancima „U istom kolu“ (Isto, str. 76. - 78.), „Deklaracija je teška varka za hrvatski narod“ (Isto, str. 154. - 155.) i „Objašnjenje“ (Isto, str. 174. - 175.).

6 Vidi Šımun Novaković, „Reakcije partijskih organa na pojavu Deklaracije o nazivu i položaju hrvatskog jezika prema pisanju nekih srbijanskih tiskovna", Mostariensia, Mostar, god. XXIII. (2019.) br. 1., str. 7. - 39. 
i Matičini ogranci, održavani su i radnički prosvjedi, a obični su građani i neformalne grupe otvorenim pismima izražavali svoje stavove o Deklaraciji.

Iako se dio gore spomenute literature bavi i kronološkim prikazom reakcija na Deklaraciju, malo se pisalo o reakcijama i raspravama u republičkim i saveznim organima, a nema ni sustavnijega prikaza reakcije neformalnih grupa i pojedinaca. U cilju popunjavanja gore navedenih praznina ovim radom želimo, na temelju izvješćivanja Politike i Borbe, prikazati tijek rasprava u republičkim i saveznim vijećima kao i općenito reakcije u izvapartijskim strukturama o Deklaraciji. Pokušat ćemo pronaći odgovore na pitanja koja su republička i savezna tijela raspravljala o Deklaraciji, kakve su stavove zauzimala prema njoj, kakav su odnos prema Deklaraciji imala šira javnost i obični građani te, naposljetku, jesu li stavovi republičkih i saveznih vijeća imali izravna utjecaja na život i znanstveni rad potpisnika.

\section{Ukratko o reakcijama hrvatskih partijskih organa}

Hrvatske su partijske strukture više od mjesec dana bile zaokupljene traženjem odgovora na pitanje tko stoji iza Deklaracije, utvrđivanjem odgovornosti i kažnjavanjem potpisnika. O Deklaraciji se raspravljalo već na sjednici Izvršnoga komiteta CK SK Hrvatske 21. ožujka 1967. godine. Također su Predsjedništvo i Izvršni komitet CK SK Hrvatske na zajedničkoj sjednici 3. travnja 1967. godine razmatrali situaciju nastalu poslije objavljivanja Deklaracije. Tada je odlučeno da se plenum, planiran za 4. travnja 1967. godine, odgodi desetak dana u cilju potpunije koordinacije rada s CK SK Jugoslavije i centralnim komitetima ostalih republika.7 Završne su rasprave o Deklaraciji vođene 19. i 20. travnja 1967. na sjednici CK SK Hrvatske. Tada su opširna izlaganja imali Mika Tripalo i Vladimir Bakarić, a Pero Pirker podnio je izvješće o poduzetim političkim mjerama i izrečenim kaznama. ${ }^{8}$

Usp. „Odložen plenum CK SK Hrvatske“, Borba, god. XXXII., br. 91., 4. travnja 1967., str. 1.

8 Prema izvješću Pere Pirkera partijska su tijela utvrdila odgovornost sto trideset članova iz institucija potpisnica, od čega sedamdeset komunista. Konkretne kazne su izrečene trideset 
Posebnu je revnost u rasvjetljivanju okolnosti nastanka kao i utvrđivanju političke odgovornosti i izricanju stegovnih mjera potpisnicima pokazao Gradski komitet Saveza komunista Zagreba koji je o Deklaraciji raspravljao 21. i 24. ožujka 1967. Nakon donesenih zaključaka o provođenju postupka utvrđivanja stupnja odgovornosti komunista koji su sudjelovali u donošenju Deklaracije, uslijedili su sastanci aktiva i osnovnih organizacija Saveza komunista institucija potpisnica Deklaracije. Čini se da postupak izricanja stegovnih mjera nije išao odgovarajućom dinamikom jer je Gradski komitet Saveza komunista Zagreba 1. travnja 1967. godine održao novu sjednicu na kojoj se razmatralo provođenje zaključaka sa sjednice od 24. ožujka. Posljednja sjednica na kojoj su zagrebački komunisti raspravljali o Deklaraciji održana je 12. travnja 1967. O Deklaraciji se raspravljalo i 22. ožujka 1967. godine na Petoj plenarnoj sjednici Glavnoga odbora Socijalističkoga saveza radnoga naroda Hrvatske.

\section{Rasprave u hrvatskim republičkim tijelima}

Nakon negativnih reakcija partijskih struktura u rasprave su se o Deklaraciji uključila i hrvatska republička tijela. ${ }^{9} \mathrm{~S}$ obzirom na to da je $D e-$ klaracija dostavljena Saboru SR Hrvatske, kao nadležnome predlagaču amandmana na Ustav SFRJ, glavnina se rasprava zbog specifičnosti njegova tadašnjeg ustroja vodila u različitim saborskim vijećima. ${ }^{10}$

četvorici članova Saveza komunista, od čega je deset članova izbačeno iz Saveza komunista. Vidi Š. NovaKović, $n$. $d j$., str. 18.

9 Djelomično se problematike rasprava u hrvatskim saborskim vijećima dotaknuo M. Samardžija koji je u svojoj knjizi donio izlaganja dr. Vladimira Bakarića, Josipa Manolića i Stipe Mesića sa sjednice Republičkoga vijeća Sabora SR Hrvatske od 30. ožujka 1967. (Deklaracija..., str. 205. - 217.), zaključke Prosvjetno-kulturnoga vijeća Sabora SR Hrvatske (Isto, str. 225. - 227.), izlaganja Ivana Šibla, predsjednika Prosvjetno-kulturnoga vijeća (Isto, str. 237. - 239.), te članova Vijeća Živka Bjelanovića (Isto, str. 240. - 241.) i Jure Kaštelana (Isto, str. 242. - 243.).

10 „Ustavom SRH iz 1963. godine (NN 15/1963), Sabor SRH ustrojen je kao peterodomno tijelo. Čini ga 5 domova (vijeća): 1. Republičko vijeće, 2. Privredno vijeće, 3. Prosvjetno-kulturno vijeće, 4. Socijalno-zdravstveno vijeće i 5 . Organizaciono-političko vijeće. Zakone i druge akte donosi Republičko vijeće ravnopravno s onim vijećem Sabora iz područja čije nadležnosti se konkretni zakon ili drugi akt donosi.“ <arhinet.arhiv.hr/details.aspx?ItemId=3_1450> (29. siječnja 2020.). Privredno je vijeće raspravljalo o stanju u oblasti privrede, financija, 
Prva je rasprava nekoga saborskoga vijeća o Deklaraciji održana tek 29. ožujka 1967. godine na sjednici Privrednoga i Socijalno-zdravstvenoga vijeća. Predsjednici su spomenutih vijeća Dušan Dragosavac i Tode Đuruvija izvijestili „poslanike da radni kolektivi, opštinske skupštine i društveno-političke organizacije sve odlučnije traže od sabora najenergičnije raskrinkavanje inicijatora i potpisnika 'deklaracije ${ }^{{ }_{11}}$. Navedena su se vijeća

jednoglasno pridružili talasu protesta radnih ljudi Hrvatske i jednodušno osudili „Deklaraciju o nazivu i položaju hrvatskog književog jezika“, kvalifikujući je - kako po sadržaju, tako i po načinu donošenja - kao neprijateljski akt uperen protiv najveće tekovine narodne revolucije - bratstva i jedinstva naših naroda. Veća su jednoglasno odbacila zahtev da se o "Deklaraciji“ raspravi u saborskim telima u debati o promeni Ustava Socijalističke Republike Hrvatske, koji je Saboru ranije podnela Matica hrvatska u ime potpisnika „Deklaracije ${ }^{“_{12}}$.

Privredno je vijeće svojim zaključcima tražilo od nadležnih saborskih i drugih organa, koji sudjeluju u financiranju ustanova - potpisnica Deklaracije - da preispitaju aktivnosti i stupanj razvijenosti samoupravnih odnosa u tim ustanovama, a od CK SK Hrvatske i Glavnoga odbora SSRN Hrvatske „da ubrzaju raščišćavanje političke odgovornosti članova ovih

komunalnih poslova i urbanizma, Socijalno-zdravstveno o stanju u području narodnoga zdravlja, socijalne zaštite, socijalnoga osiguranja i radnih odnosa, Prosvjetno-kulturno o stanju u prosvjeti, znanosti, umjetnosti i drugim područjima kulture i fizičke kulture, a Organizaciono-političko vijeće radi na izgradnji ustavnoga sistema, posebno društvenoga samoupravljanja (ostvarivanje samoupravljanja u radnim i drugim organizacijama, općini i kotaru), budžetskoga sistema i budžetske kontrole, sistema pravosuđa i državne uprave. Opširnije o ustroju, djelokrugu rada i nadležnostima saborskih vijeća vidi Sumarni inventar - Sabor Socijalističke republike Hrvatske 1945-1982, izradio: Nenad Bukvić, Hrvatski državni arhiv, Zagreb, 2012.

${ }^{11}$ „Deklaracija - neprijateljski akt protiv bratstva i jedinstva“, Borba, god. XXXII., br. 86., 30. ožujka 1967., str. 5. Iako su tekstovi u Borbi i Politici pisani tzv. istočnom varijantom hrvatskosrpskoga jezika, u citate nismo unosili pojašnjenja i upozorenja na riječi koje nisu u duhu današnjega hrvatskoga jezika. Također je bitno napomenuti da u novinskim člancima postoji dosta pravopisnih šarolikosti, posebno kod pisanja velikoga slova i miješanja ekavskoga i ijekavskoga refleksa jata. Stoga se navedene šarolikosti u citatima pojavljuju i u ovome radu.

${ }_{12}$ „Treba ispitati kakvi su odnosi samoupravnih ustanova-potpisnica“, Politika, god. LXIV., br. 19211., 30. ožujka 1967., str. 6. 
foruma i organizacija koji su bili sudionici donošenja Deklaracije ${ }^{{ }_{113}}$. Pozivano je i na utvrđivanje kaznene odgovornosti institucija i sastavljača Deklaracije. U stavu se Socijalno-zdravstvenoga vijeća traži da se „inspiratori i inicijatori iznesu pred javnost i podvrgnu društvenoj odgovornosti (...) Donoseći taj akt mimo nadležnih i samoupravnih organa i kolektiva autori 'Deklaracije' su pokazali izrazit primjer zloupotrebe svoga položaja ${ }^{{ }^{14}}$. Tiskovine su redovito prenosile i dijelove izlaganja pojedinih diskutanata. Zastupnica Desanka Ljubotina je, uz traženje objavljivanja imena potpisnika, postavila pitanje „do kada će inicijatori i potpisnici Deklaracije biti u anonimnosti [te] ukoliko takvih ljudi ima i među poslanicima Sabora, javnost o tome treba obavestiti, a oni treba da snose sve posledice “. ${ }^{15}$ U raspravi je sudjelovao i Anđelko Jurčan iz Poreča koji je naveo da je Deklaracija u Istri „izazvala zgražanje ljudi svih nacionalnosti koje tamo žive ${ }^{{ }^{\prime 16}}$, te, također, tražio objavljivanje imena potpisnika Deklaracije. U raspravi su sudjelovali i Nikola Papić, Franko Franulović, Emil Ludviger i Vladimir Imrović, koji su u Deklaraciji vidjeli akt protiv bratstva i jedinstva te pozivali na utvrđivanje odgovornosti. ${ }^{17}$

Republičko i Organizaciono-političko vijeće Sabora SR Hrvatske su 30. ožujka 1967. godine raspravljali o Deklaraciji. Najprije su predsjednici spomenutih vijeća Boris Bakrač (Republičko vijeće) i Leo Geršković (Organizaciono-političko vijeće) u svojim uvodnim izlaganjima obavijestili zastupnike da „Saboru i republičkim forumima društveno-političkih organizacija stalno stižu pisma opštinskih i sreskih skupština, radnih organizacija, zborova birača, organizacija SSRH i pojedinaca - u kojima se najoštrije osuđuje 'Deklaracija o nazivu i položaju hrvatskog književnog jezika' i najenergičnije traži da potpisnici Deklaracije, posebno njeni

${ }^{13}$ "Zaključci Republičkog i Organizaciono-političkog vijeća Sabora Hrvatske“, Politika, god. LXIV., br. 19212., 31. ožujka 1967., str. 6.

14 „Treba ispitati kakvi su odnosi samoupravnih ustanova-potpisnica“, Politika, god. LXIV., br. 19211., 30. ožujka 1967., str. 6.

15 Isto.

16 Isto.

${ }_{17}$ Vidi „Deklaracija - neprijateljski akt protiv bratstva i jednistva“, Borba, god. XXXII., br. 86., 3o. ožujka 1967., str. 5. 
inicijatori i začetnici, snose punu političku i društvenu odgovornost ${ }^{{ }^{\prime 18} 8}$. U nastavku su sjednice zastupnici detaljnije informirani o zahtjevu Matice hrvatske da se Deklaracija uzme u razmatranje tijekom rasprava o promjeni Ustava. Boris Bakrač iznio je mišljenje da „nije ‘Deklaracija' ta koju bi Sabor trebalo da stavi na dnevni red i na pretres, već posljedice koje je ona izazvala“" ${ }^{{ }_{119}}$, a Geršković je predložio da se „odbaci svaka inicijativa koja traži raspravu o zahtevima Deklaracije prilikom diskusije o ustavnim promenama ${ }^{{ }^{20}}$. Nakon rasprave u kojoj je sudjelovao veći broj diskutanata ${ }^{21}$ Deklaracija je odbijena „pored ostalog i zbog toga što je takvoj inicijativi javnost već dala pravu ocenu - kao podmukloj i opasnoj diverziji protiv bratstva i jedinstva i želji pojedinaca za povratak na staro $^{{ }^{22}}$.

Politika je posebno opširno pisala o izlaganjima Vladimira Bakarića i Milana Nožinića, dok je Borba dala prostora izlaganjima i nekih drugih diskutanata. V. Bakarić je na početku svoga izlaganja naveo da smatra velikim uspjehom što je „naš narod u osudi tih postupaka pokazao tako veliko jedinstvo i veliku razboritost, sa čime možemo biti ponosni “ ${ }^{{ }_{23}}$. Osvrnuo se i na svoje sudjelovanje u donošenju svih prethodnih ustava, pa samim tim i formulacijama jezika koje se u njima pojavljuju. Napomenuo je da je ustavima iz 1946. i 1953. godine bilo formulirano da se zakoni i drugi opći propisi Federativne Narodne Republike Jugoslavije objavljuju na jezicima narodnih republika, a prema Ustavu iz 1964. godine „savezni zakoni i drugi opšti akti saveznih organa objavljuju se $(. ..) \mathrm{u}$ autentičnim tekstovima na jezicima naroda Jugoslavije:

${ }_{18}$ „Osnovni stavovi 'Deklaracije’ su neprijateljski prema današnjoj fazi socijalističke revolucije“, Politika, god. LXIV., br. 19212., 31. ožujka 1967., str. 5.

19 Isto.

20 Isto.

${ }^{21}$ U raspravi su sudjelovali Josip Lazović, Rade Bulat, Vinko Bilić, Josip Manolić, Pero Brković, Drago Žanić, Petar Kriste, Anica Magašić, Milan Nožinić, Stipe Mesić, Blaž Berić, dr. Vladimir Bakarić, Dušan Štrbac, Mišo Kmecik, Rada Juranović, Ivan Ribarić, Anka Bučan, Josip Ninić, Ante Petercol, Darinka Puškarić, Ljubo Prvan i dr. Vidi „Osnovni stavovi Deklaracije su neprijateljski prema današnjoj fazi socijalističke revolucije“, Politika, god. LXIV., br. 19212.,31. ožujka 1967., str. 6.

${ }^{22}$ „Utvrditi i zakonsku odgovornost autora 'Deklaracije', Borba, god. XXXII., br. 87., 31. ožujka 1967., str. 4.

${ }^{23}$ „Reč dr Vladimira Bakarića“, Politika, god. LXIV., br. 19212., 31. ožujka 1967., str. 6. 
srpskohrvatskom odnosno hrvatskosrpskom, slovenskom i makedonskom". ${ }^{24}$ Potom je obrazlagao da navedena formulacija znači da se zakoni donose na jezicima naroda, a ne i na jezicima narodnosti, dok je stvar svake republike kako će jezik nazivati. Bakarić se osvrnuo i na korištenje termina u nazivu jezika „kaže se: hrvatskosrpski odnosno srpskohrvatski, ali se spominju i jedan i drugi? Da li su to sinonimi? Ako jesu, ipak njihovo odvojeno nabrajanje mora imati neki svoj smisao. Inače, ne bi mogli naći mesto $\mathrm{u}$ jednom zakonskom tekstu“. ${ }^{25}$ Bakarić se dotaknuo i jezika na kojem su doneseni akti AVNOJ-a te uporabe jezika u Saveznoj skupštini i JNA. ${ }^{26}$

Član Republičkoga vijeća i Društva književnika Hrvatske Milan Nožinić u svome je izlaganju govorio o okolnostima donošenja Deklaracije. Prema njegovim riječima članovi Društva nisu dobili nikakav materijal prije sjednice, a o Deklaraciji se raspravljalo pod točkom dnevnoga reda Akcija kulturnih institucija o ravnopravnosti jezika. ${ }^{27}$ Nožinić je naveo:

premda su mnogi književnici Hrvatske bili u dilemi kada su pročitali neko površno, neko na brzinu - bili su dezorjentisani, ali uglavnom se stvorila atmosfera, da to treba, da je to neophodno, da se tu ne može izmeniti nijedna formulacija, pošto to nije samo deklaracija Društva književnika Hrvatske, već i drugih 17 kulturnih institucija, pa bi to onda zahtevalo novu proceduru, a treba žuriti da bi se dobilo u vremenu - kako bi 15. marta bila kao amandman dostavljena Saveznoj skupštini i Saboru Hrvatske za promenu Ustava ${ }^{28}$.

Svojom raspravom potvrđuje ulogu Miroslava Krleže u donošenju Deklaracije, ali i otvara pitanje uloge nekih drugih članova Saveza komunista jer je u svojoj raspravi naveo da je kuloarski bilo „protureno da

\footnotetext{
24 Isto.

25 Isto.

26 Sadržaj je Bakarićeva govora objavio Vjesnik 31. ožujka 1967. Vidi M. SAMARdžıj, Deklaracija..., str. 205. -213 .

27 O aktivnostima koje su prethodile donošenju Deklaracije, kao i aktivnostima institucija potpisnica vidi JosıP PAvičıć „Deklaracija o nazivu, položaju i budućnosti hrvatske samostalnosti“ Jezik, Zagreb, god. LXIV. (2017.) br. 1., str. 14. - 29.

${ }_{28}$ „Milan Nožinić: Kako je došlo do aklamacione odluke o 'Deklaraciji'“, Politika, god. LXIV., br. 19212., 31. ožujka 1967., str. 6.
} 
iza teksta Deklaracije stoje ugledni drugovi, članovi centralnog komiteta, prisutan je Miroslav Krleža - dakle sve je u redu“" ${ }^{29}$. Nožinić je govorio i o atmosferi i stavovima koji su dolazili do izražaja na sjednici aktiva komunista Društva književnika Hrvatske 29. ožujka 1967. Po njemu je bilo zaprepaštenje „slušati pojedine komuniste koji ustaju u obranu 'Deklaracije' i dan-danas, nakon svega što je naša javnost rekla, nakon ovih divnih pisama koja su objavljena u štampi, i nakon onoga što je drug Tito rekao na Kosovu i Metohiji, nakon svega što je rekao Izvršni komitet, što je zaključio Gradski komitet, itd.“30. Nožinić je posebno osudio objašnjenje potpisnika po kojima Deklaracija nije imala za cilj političku akciju, ${ }^{31}$ „nego su joj političke implikacije nametnuli reagovanje javnosti i Centralni komitet, koji je, tobože, nepotrebno uneo uzbuđenje u javnost “" ${ }^{\text {“2 }}$. U Deklaraciji vidi smišljeni politički akt i po tome što je tekst prije objavljen u tisku nego što je stigao u Saveznu skupštinu: „šta više ona je pre nego Saboru bila poslata beogradskoj grupi šovinista koji su odmah napisali 'Predlog za razmišljanje'“. ${ }^{33}$ Iz njegova je izlaganja

29 „Utvrditi i zakonsku odgovornost autora deklaracije“, Borba, 3god. XXXII., br. 87., 31. ožujka 1967., str. 4. Neki su pojavu Deklaracije dovodili i u vezu s Vladimirom Bakarićem. Usp. Stjepan BABIĆ, „O Deklaraciji- činjenice i pretpostavke“, Kolo, br. 1. - 2., 2009., <http:// www.matica.hr/kolo/314/o-deklaraciji-cinjenice-i-pretpostavke-20686/> (20. I. 2019.). Nakon demokratskih promjena Miko Tripalo odbacio je mogućnost da je iza Deklaracije stajao Bakarić, ocjenjujući da je bio suviše oprezan za tako nešto. (J. PAvičić, Deklaracija..., str. 20).

3o „Milan Nožinić: Kako je došlo do aklamacione odluke o 'Deklaraciji'“, Politika, god. LXIV., br. 19212., 31. ožujka 1967., str. 6.

${ }_{31}$ Ovdje se misli na izjavu koju su potpisale institucije potpisnice Deklaracije na sjednici održanoj u Matici hrvatskoj 24. ožujka 1967. godine. U njihovoj se izjavi navodi da su razmotrili „neočekivane i politički štetne posljedice koje su nastupile u povodu objavljivanja deklaracije“. „Izjava institucija koje su potpisale Deklaraciju“, Politika, god. LXIV., br. 19207., 26. ožujka 1967., str. 8.), te iznose objašnjenje da je Deklaracija „nastala u atmosferi opće demokratizacije našega života, a i u situaciji u kojoj se, upravo na današnji dan, zaključuje primanje prijedloga za izmjenu Ustava SFRJ. Potpisane su institucije nakon stručne rasprave došle do rezultata koje su iznijeli u deklaraciji o problemima o kojima se u našoj dnevnoj i stručnoj štampi govori već nekoliko godine. Potpisanim institucijama je bilo jasno da neki zaključci novosadskog dogovora zahtijevaju opširniju raspravu u hrvatskoj javnosti kao i sporazumijevanje sa znanstvenim institucijama iz ostalih republika hrvatskosrpskog jezičnog područja." Isto.

32 „Utvrditi i zakonsku odgovornost autora deklaracije“, Borba, god. XXXII., br. 87., 31. ožujka 1967., str. 4.

33 Isto. 
vidljivo da su potpisnici Dekaracije, kao poticaj njezinu donošenju, navodili i poteškoće koje su se pojavljivale prilikom sastavljanja Rječnika suvremenog hrvatskosrpskog jezika, ${ }^{34}$ odnosno "da o strane pojedinih drugova u Beogradu, odnosno stručnjaka, doživljavaju nepremostive prepreke, da je to opstruiranje bilo takvo da je dovelo do nemogućnosti daljnju aktivnost i dalji rad na tome ". ${ }^{35}$ Budući da je jezik živa stvar koja se neprestano razvija, na kraju je Nožinić „duboko respektujući Novosadski sporazum - pledirao za jedan novi dogovor koji bi probleme nastale u međuvremenu zajednički otklonio“"36.

Dok je Politika prenijela samo Bakarićevo i Nožinićevo izlaganje, u Borbi se nalaze dijelovi izlaganja i nekih drugih diskutanata. Josip Lazarević naveo je da ljudi iz njegova izbornog područja iz Istre $u$ Deklaraciji vide „akt izrazite političke prirode, posledicu smišljene akcije jednog užeg samozvanog kruga ljudi koji žele povratak na zloglasna bratoubilačka vremena“" ${ }^{37}$, a Rade Bulat aktualizirao je pitanje neobjavljivanja imena potpisnika Deklaracije te predložio CK SK Hrvatske i Glavnomu odboru SSRNH da se „ubrza raščišćavanje političke odgovornosti njihovih članova imajući naročito u vidu da su neki potpisnici danas ugledni društveno-politički radnici predviđeni za visoke funkcije u Saboru“" ${ }^{\text {" }}$. Vinko Bilić tražio je da potpisnici budu „uklonjeni i onemogućeni u javnom i političkom životu. Birači više ne žele da budu predstavljeni - u bilo kojoj prilici - od ljudi koji imaju direktne ili indirektne veze

34 Ovdje se vjerojatno misli na pismo koje je Matica hrvatska uputila Matici srpskoj vezano za neka otvorena pitanja koja su posebno došla do izražaja 20. i 21. veljače 1967. godine na sjednici redakcije Rječnika suvremenoga hrvatskosrpskoga jezika. Tada su M. Stevanović i Ž. Milisavac problematizirali pitanje navođenja Crnogoraca kao posebnoga naroda u predgovoru spomenutoga Rječnika. Ž. Milisavac izjavio je: „Ako vi budete postavljali problem Crnogoraca kao posebnog naroda, mi ćemo tražiti da se i Dalmatincima prizna status posebnog naroda!!“ „Pismo Matice hrvatske Upravnom odboru Matice srpske“, Politika, god. LXIV., br. 19207., 26. ožujka 1967., str. 8 i „Odgovor Živana Milisavca na članak 'Vjesnika', Politika, god. LXIV., br. 19207., 26. ožujka 1967., str. 8.

35 „Milan Nožinić: Kako je došlo do aklamacione odluke o Deklaraciji“, Politika, god. LXIV., br. 19212.,31. ožujka 1967., str. 6.

36 Isto.

37 „Utvrditi i zakonsku odgovornost autora 'Deklaracije“", Borba, god. XXXII., br. 87., 31. ožujka 1967., str. 4.

${ }^{38}$ Isto. 
sa idejama sadržanim u Deklaraciji“ “39, a Josip Manolić upozorio je da moramo biti „svesni toga da još ima organizovanih neprijateljskih snaga koje kod nas deluju protiv socijalizma i jedinstva zemlje ${ }^{{ }_{400}}$. Dušan Štrbac naveo je da je Deklaracija unijela veliko uzbuđenje u krajeve gdje žive Hrvati i Srbi. Pero Brković postavio je pitanje javnomu tužitelju je li „pokrenuo postupak protiv inspiratora 'Deklaracije' i do kojih je rezultata došao" ${ }^{41}$, a pokretanje kaznene odgovornosti podržao je i Blaž Perić po kojemu ne treba „prezati od objavljivanja imena potpisnika, jer smo mi žrtvovali i mnogo veće ličnosti koje su se ogrešile o principe naše revolucije“42. Odgovorio im je javni tužitelj Ljudevit Dezmar koji je „dao uverenje Saboru Hrvatske da 'Javno tužilaštvo u vezi sa 'Deklaracijom' nastoji da - u okvirima svojih prava i ovlašćenje koja proizilaze iz krivičnog zakonodavstva - što savesnije ispuniti svoju dužnost"“.43 Također je zamolio da mu ostave vremena da provjeri ima li u donošenju Deklaracije elemenata kaznenoga djela iz članka 119. Kaznenoga zakona „koji govori o propagandi ili drugim oblicima unošenja mržnje i razdora među jugoslovenske narode “44.

Politika je u posebnome dijelu prenijela usvojene zaključke Republičkog vijeća kojima se traži:

1) Da Sabor pozove, kako izvršne organe Republike, tako i organe institucija potpisnika Deklaracije da utvrde stupanj društvene i političke odgovornosti inicijatora i potpisnika Deklaracije i da o tome obavijeste Sabor.

2) Da preporuči građanima, društveno-političkim organizacijama i općinskim skupštinama da onemoguće izbor u predstavnička tijela onim pojedincima koji su odgovorni za donošenje Deklaracije i koji je podržavaju.

3) Da preporuči Centralnom komitetu SK Hrvatske i Glavnom odboru Socijalističkog saveza radnog naroda Hrvatske da ubrzaju raščišćavanje

39 Isto.

40 Isto.

${ }^{41}$ Isto.

42 Isto.

43 „Javno tužilaštvo će savesno ispuniti svoju dužnost“, Borba, god. XXXII., br. 87., 31. ožujka 1967., str. 1.

44 "Javni tužilac Hrvatske o eventualnom pokretanju krivičnog postupka“, Politika, god. LXIV., br. 19212., 31, ožujka 1967., str. 6, 
političke odgovornosti članova ovih foruma i organizacija koji su bili sudionici donošenja Deklaracije. ${ }^{45}$

Preneseni su i zaključci Organizaciono-političkoga vijeće u kojima se navodi da donošenje Deklaracije i Predloga za razmišljanje predstavlja

uzurpiranje ustavnih prava naroda od strane uske grupe. Ti akti po svojim političkim stavovima su nacionalistički, podstiču unitarističke tendencije i predstavljaju smišljenu akciju za razbijanje bratstva i jedinstva hrvatskog i srpskog naroda. Organizaciono-političko veće istovremeno izražava ogorčenost zbog napada na Jugoslavensku armiju i na njeno jedinstvo, jer je ona zalog naše slobode i nezavisnosti ${ }^{46}$.

Isto je vijeće izrazilo stav da je Deklaraciji cilj „sprečavanje izgradnje Jugoslavije kao federativne i ravnopravne zajednice njenih naroda i narodnosti i onemogućavanje zajedničkog života Hrvata i Srba u Hrvatskoj “47. U kontekstu svega navedenog Organizaciono-političko vijeće zaključilo je da se „inicijatori i organizatori 'Deklaracije' pozovu na političku i zakonsku odgovornost zbog korištenja ustavnih i demokratskih sloboda za ciljeve protivne Ustavu“48.

O Deklaraciji je raspravljalo i Prosvjetno-kulturno vijeće Sabora SR Hrvatske 31. ožujka 1967. godine. Riječ je o raspravi u jednome od „najkompetentnijih foruma pozvanih da rasprave i ocene pojavu i sadržaj ovog javnog akta i njegovih političkih i kulturnih aspekata" ${ }^{49}$, navodi se u uvodu Politikina članka. U uvodnoj je riječi predsjednik navedenoga vijeća Ivan Šibl izvijestio da je "Matica hrvatska uputila primerak 'Deklaracije', sa zahtevom za ustavne izmene i predložio da se povede

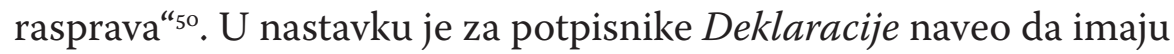

45 „Zaključci Republičkog i Organizaciono-političkog vijeća Sabora Hrvatske“, Politika, god. LXIV., br. 19212., 31. ožujka 1967., str. 6.

46 Isto.

47 Isto.

48 Isto.

49 „Potpisnici nisu imali poverenja u Savez komunista i radni narod uopšte“, Politika, god. LXIV., br. 19213., 1. travnja 1967., str. 6.

5o Isto. 
pomanjkanje klasnog kriterijuma u rešavanju nacionalnog pitanja, koje je postavljeno na potpuno neuobičajen i nedopustiv način, i bačeno $u$ javnost. Pri tome treba istaći da potpisnici nisu imali mnogo povjerenja ne samo u radničku klasu i njezine organe, organizacije i forume Saveza komunista, već i u radni narod općenito. Radili su nedemokratski, prisvojivši si pravo da u javnost daju nešto tobože u ime naroda, na što svakako nisu imali pravo. S tim su mogli poremetiti odnose između hrvatskog i srpskog naroda u Hrvatskoj i između Srba i Hrvata uopće. ${ }^{51}$

\title{
Šibl je posebno ukazao na potrebu da Prosvjetno-kulturno vijeće
}

\begin{abstract}
ima specifičan pristup, različit od drugih veća Sabora, jer je reč o radnim organizacijama čiji su predstavnici i pojedini članovi potpisnici „Deklaracije“. Te su radne organizacije predstavljene u Veću svojim izabranim predstavnicima. (...) Postupak potpisnika „Deklaracije“ začuđuje tim više što se naše Vijeće, odgovorno za rješavanje tih pitanja, osobito angažiralo na liniji razvoja samoupravljanja u radnim organizacijama prosvjete, nauke i kulture, a kao što je poznato - ova „Deklaracija“ donijeta je mimo tih organa. Postupak začuđuje i zbog toga što je Vijeće za ove četiri godine bilo uvijek široko otvoreno za sve rasprave o problematici s područja prosvjete, nauke i kulture, svim zainteresiranim stranama i političkim ljudima, bez obzira jesu li oni bili zastupnici ${ }^{52}$.
\end{abstract}

Na kraju je Šibl izrazio uvjerenje da će „kulturni radnici Hrvatske i Zagreba, znajući kakve su njihove revolucionarne tradicije, kako su bili brojno zastupljeni u oslobodilačkom ratu i revoluciji, u revolucionarnom radu pre i posle rata - lako prevladati taj žalosni događaj, tim više što se očigledno radi i o nenaučnom pristupu pitanjima jezičke problematike" ${ }_{53}$. Nakon Šibla u raspravi je sudjelovalo više diskutanata, ${ }^{54}$ a Politika prenosi samo manji dio tih izlaganja. Davor Šošić istaknuo je „da je zadatak ovog veća da sugeriše pojedinim izvršnim organima čije programe rada usvaja Sabor - kao što je, na primer, Republički fond za unapređenje kulturnih delatnosti - da povedu računa o ljudima koji se

\footnotetext{
${ }^{51}$ Isto.

${ }_{52}$ Isto.

53 Isto.

${ }^{54}$ U raspravi su sudjelovali Stevan Podrožić, Srećko Ljubljanović, Božidar Bek, Marijan Laćan, Vanda Milčetić, Milan Slani, Božo Novak, Paško Pajić, Petar Rajković i dr.
} 
nalaze u tim institucijama i organizacijama. Činjenica je (...) da se mnogi od potpisnika 'Deklaracije' nalaze u raznim odborima u kojima se ostvaruje praktična osnovna politika koju Sabor zacrtava" ${ }^{55}$. Borba donosi dijelove izlaganja još nekoliko diskutanata. Stevan Podrožić predložio je da se „potpisnici i nosioci Deklaracije uklone sa rukovodećih mesta njihovih radnih organizacija i naučnih istitucija", ${ }^{6}$ a Živko Bjelanović je za potpisnike Deklaracije naveo da su „izdali revolucionarnu tekovinu naše istorije. Jezičko jedinstvo hrvatskosrpskog jezika posledica je težnji naših naroda da se nacionalno zbliže i žive ravnopravno u jednoj zajednici“" ${ }^{47}$. U raspravi je sudjelovao i Srećko Ljubljanković koji je govorio o osudama Deklaracije u Slavoniji, a Božidar Bek o postojanju kontrarevolucionarnih snaga koje društvo vuku nazad. Božidar Novak rekao je da

\begin{abstract}
mi imamo poseban razlog i odgovornost da se osude duh i autori „Deklaracije“. I to zbog sledećeg: „Deklaraciju“ su potpisale kulturne institucije koje su nastupile u ime kulturne javnosti Hrvatske, u ime kulturnih radnika, radnih ljudi čiji smo mi predstavnici u ovom Domu. Zato želim naglasiti da u proceni težine ove političke diverzije treba početi od činjenice da od Revolucije na ovamo nije bilo pojava, koje bi više narušile ugled Hrvatske, hrvaskog naroda i hrvatske kulture ${ }^{58}$.
\end{abstract}

Na kraju se izvješća s navedene sjednice navodi da je Deklaracija načinila ogromnu štetu hrvatskoj kulturi te da institucije potpisnice Deklaracije „nisu konsultovale članstvo koje ih sačinjava [te] da 'Deklaracija,' načinom svog nastanka, isključivanjem javnosti i bez uobičajene prethodne naučne rasprave, predstavlja negiranje slobodnog, stvaralačkog naučnog i kulturnog rada, za koji se Prosvetno-kulturno veće u svojoj četverogodišnjoj praksi neprekidno zalagalo" ${ }^{\text {59 }}$. Na sjednici je također

55 „Potpisnici nisu imali poverenja u Savez komunista i radni narod uopšte“, Politika, god. LXIV., br. 19213., 1. travnja 1967., str. 6.

56 „Deklaracija' je nanela ogromnu štetu ugledu hrvatskog naroda i kulture“, Borba, god. XXXII., br. 88., 1. travnja 1967., str. 4.

57 Isto.

${ }^{8}$ Isto.

59 „Potpisnici nisu imali poverenja u Savez komunista i radni narod uopšte“, Politika, god. LXIV., br. 19213., 1. travnja 1967., str. 6. 
utvrđeno da se objavljivanjem „Deklaracije' pokušalo dati maha šovinističkim, unitarističkim i birokratskim snagama, koje su je prihvatile kao dobrodošlu zastavu u svojoj borbi protiv socijalizma, demokracije i intenzivne izgradnje društva samoupravljača“" ${ }^{\circ}$. Vijeće je izrazilo i negodovanje prema izjavi potpisnika Deklaracije jer „takvo ponašanje izaziva nepovjerenje javnosti u ove institucije i otežava postojeće napore i ovog Vijeća na razrješavanju aktualnih problema na svim područjima razvoja prosvete, kulture i nauke Hrvatske. Prosvetno-kulturno veće tvrdi da hrvatski književni jezik i hrvatska kultura nisu ugrožen kako to pokušava imputirati 'Deklaracija'“61. U zaključcima se Prosvjetno-kulturnoga vijeća poziva organe

1) Republike tako i radne ljude i organe upravljanja institucija i organizacija - potpisnika „Deklaracije“ da utvrde stepen društvene i političke odgovornosti inicijatora i potpisnika „Deklaracije“ i da o tome obavijeste Prosvetno-kulturno vijeće.

2) Preporučuje se građanima, društveno-političkim organizacijama, opštinskim skupštinama i radnim organizacijama na području prosvjete, kulture i nauke da onemoguće izbor u predstavnička tijela onim pojedincima koji su odgovorni za donošenje „Deklaracije“ i koji je podržavaju.

3) Daje punu podršku vijećima Sabora i političkim forumima da do kraja izvrše zahtjeve kulturne javnosti da odgovorni akteri ove diverzije snose pune društvene i političke posljedice.

4) Da se u interesu ugleda hrvatske kulture i njenih institucija objave i pozovu na odgovornost malobrojni inicijatori i potpisnici „Deklaracije“. ${ }^{\prime 2}$

I Skupština Republičke privredne komore Hrvatske je na sjednici 31. ožujka 1967. godine osudila Deklaraciju „ocenjujući je kao akt koji koristi jedino protivnicima samoupravljanja i društvene i privredne reforme. (...) Radnici nemaju interesa za jezičke svađe (...) posebno su ogorčeni kad one imaju nacionalističke i u osnovi neprijateljske implikacije ${ }^{{ }^{63}}$.

\footnotetext{
6o Isto.

61 Isto.

62 Isto.

${ }_{63}$ "Deklaracija korisna jedino protivnicima samoupravljanja i reforme“, Politika, god. LXIV., br. 19214., 2. travnja 1967., str. 8.
} 
Iako je o Deklaraciji bilo govora već 21. ožujka 1967. godine na sjednici Savjeta za naučni rad Hrvatske, ${ }^{64}$ o njoj se detaljnije raspravljalo tek 14. travnja $1967 .{ }^{65}$ Razlog je odgode vjerojatno činjenica da 21. ožujka nije još bio dovoljno jasan partijski stav o Deklaraciji i njezinim potpisnicima. Kada je napokon sjednica održana, Savjet se „pridružio široko izraženom mišljenju naše javnosti osuđujuću deklaraciju kao težak udarac bratstvu i jedinstvu naših naroda" ${ }^{\text {"66 }}$. U raspravi su neki diskutanti istaknuli da Savjet nema formalne ingerencije nad potpisnicama Deklaracije, ali su potpisnici bili dužni konzultirati ili bar upoznati spomenuti Savjet s tekstom Deklaracije. Utvrđeno je da je navedeni Savjet „redovno financijski pomagao naučne radove na području hrvatskosrpskog jezika i književnosti i da je obrada tih pitanja bila sprovedena na koncepciji jedinstvenog jezika"67.

\section{Rasprave u jugoslavenskim saveznim tijelima}

Relativno je brzo Deklaracija postala temom rasprava saveznih skupštinskih tijela. O njoj se raspravljalo već 21. ožujka 1967. godine na sjednici Odbora Saveznoga vijeća za društveno-ekonomske odnose. ${ }^{68}$ U raspravi se Deklaracije dotaknuo Pero Car koji je ukazao na potrebu preciznijega reguliranja ustavom zagarantiranih prava naroda i narodnosti jer nepreciznosti predstavljaju element koji koriste nositelji

64 O ustroju i radu navedenoga savjeta vidi BRNARD STULLI, „Arhivska služba i petogodišnji program naučno-istraživačkog rada u oblasti historije“, Arhivski vjesnik, Zagreb, god. IV. v. (1962.) br. 1., str. 360. - 372 .

65 Vidi „Savet za naučni rad Hrvatske raspravljaće o 'Deklaraciji' na jednoj od svojih narednih sednica“, Politika, god. LXIV., br. 19203., 22. ožujka 1967., str. 7.

66 „Savet je uvek financirao naučne radove o jeziku na osnovi novosadskog dogovora“, Politika, god. LXIV., br. 19227., 15. travnja 1967., str. 8.

67 Isto.

68 „Saveznu skupštinu od 1964. sačinjavali su Savezno vijeće, kao vijeće delegata građana u općinama i republikama, i Privredno vijeće, Prosvjetno-kulturno vijeće, Socijalno-zdravstveno vijeće i Organizacijsko-političko vijeće, kao vijeća delegata radnih ljudi u radnim zajednicama. Svako vijeće imalo je po 120 poslanika, koji su se birali u skladu s normom da se jedan poslanik bira na isti broj stanovnika i da se u jednoj ili više općina, kao izbornoj jedinici, bira po jedan poslanik za svako vijeće. U Savezno vijeće biralo je i republičko vijeće svake republičke skupštine po deset poslanika iz reda svojih članova“. <https://www.wikiwand. com/bs/Skupština_Socijalističke_federativne_republike_Jugoslavije>, (25. I. 2020.). 
različitih društvenih pojava te se u navedenome kontekstu osvrnuo i na Deklaraciju koja

nije izraz strahovanja da je jezik jednog naroda ugrožen. Za takvo strahovanje najmanje ima razloga u samoj Hrvatskoj. To dobro znaju i malobrojni, izolovani potpisnici deklaracije. Međutim, oni se hvataju upravo za neprecizne ustavne odredbe koje se tiču notornih prava naroda i narodnosti, pa pokušavaju da narodu nametnu diskusiju. U tome se, na istoj liniji, nalaze i malograđani i komunisti s provincijalnim shvatanjima. Ljudi u Hrvatskoj, međutim, duboko se stide zbog te pojave i zgražaju se nad njom kao i nad pitanjima koja se pokreću u deklaraciji ${ }^{69}$.

Deklaracija je bila tema i sjednice Saveznoga vijeća Savezne skupštine 24. ožujka 1967. godine. Iako je težište rasprava bilo na problematici sigurnosti prometa, elektroprivrede te usvajanja izvješća povjerenstava koja su radila na prijedlozima promjene Ustava, tiskovine su dosta prostora dale izlaganju Jure Galića iz Livna koji je rekao da nije filološki stručnjak, ali je „siguran da se ovde ne radi o argumentima filološke prirode: radi se, naprotiv o argumentima političke prirode koji se, da budem precizniji, ne iznose sada prvi put. Kobne 1941. godine, kada je okupatoru bilo stalo da nas što više podeli i podeljene lakše iskorenjuje, njegove sluge u Hrvatskoj u svojoj antinarodnoj, antihrvatskoj delatnosti počele su sa sličnim čišćenjem jezika “" ${ }^{\text {" }}$. Ukazao je na sličnost Deklaracije s pisanjem Hrvatskog naroda 9. lipnja 1941. godine, ${ }^{71}$ nazivajući je mračnjačkim činom koji sliči na puč i na „svojevrstan politički udar, protiv najveće i najlepše tekovine naša narodnooslobodilačke borbe, na bratstvo i jedinstvo naših naroda. Ovo tim pre što je pripremana $u$

69 „Podrška promenama Ustava, zamerka postupku“, Politika, god. LXIV., br. 19203., 22. ožujka 1967., str. 5 .

70 „Prilagođavanje Ustava društvenom razvitku“, Borba, god. XXXII., br. 81., 25. ožujka 1967., str. 4. Vidi i M. SAmArdžıJA, Deklaracija..., str. 144. - 147.

71 U spomenutome se tekstu Hrvatskog naroda navodi da „bez obzira na veliko područje sličnosti koje postoje između suvremenog hrvatskog i srpskog književnog jezika, ni povijesni razvoj, ni stvarno današnje stanje ne dopušta da se hrvatski i srpski književni jezik smatraju jednim jezikom i jednim srpskohrvatskim ili hrvatskosrpskim jezikom jer bi svako takvo sjedinjavanje dvaju svojevrsnih književnih jezika krnjilo potpunost i nezavisnost hrvatskog jezičnog zakonodavstva“. „Prilagođavanje Ustava društvenom razvitku“, Borba, god. XXXII., br. 81., 25. ožujka 1967., str. 4. 
tajnosti, bez uvida javnosti i protiv svih normi koje su proklamovane Ustavom i drugim zakonima, kao i svim dobrim običajima“.72 Galić je govorio i u ime Hrvata u BiH koji, prema njegovim riječima,

sa svom ogorčenošću osuđuju ovaj pamflet. Nama je dosta ova granica koju su između nas i naše braće sa kojima u zajednici živimo i radimo, Srba i Muslimana, u prošlosti postavljali razni nacionalistički i šovinistički elementi. (...) Narod Bosne i Hercegovine podjednako i Srbi, Hrvati i Muslimani, dobro se međusobno razumeju i to na jednom jeziku, koji je zajednički i materinski svima njima. Oni se na tom jeziku međusobno ne ugrožavaju, rešavaju složno sva pitanja jezika"73. Galić je također istaknuo da „hrvatski radni narod nikada nije konsultovan od potpisnika Deklaracije, koji uobražavaju da govore u njegovo ime, niti su u njoj odražene njegove misli i njegove želje "74 te je potpisnicima Deklaracije predbacio da nisu postupili „kao naučnici, već kao obični politički špekulanti ${ }^{75}$.

O Deklaraciji se raspravljalo i 27. ožujka 1967. godine na sjednici Prosvjetno-kulturnoga vijeća Savezne skupštine. Tiskovine su opširno prenijele sadržaj izlaganja Zdenka Štambuka koji je oštro napao potpisnike Deklaracije i Predloga za razmišljanje, pri čemu je posebno aktualizirao pitanje jesu li potpisnici imali pravo bez odobrenja svojih birača staviti potpis i dati suglasnost akciji „koja ima nedvosmisleno politički karakter i koja u međunacionalne odnose u našoj zemlji ubacuje diverziju, kakvu već odavno nismo doživeli. Ja mislim da to oni nisu smeli da učine i da će ih birači sasvim sigurno pozvati na odgovornost zbog te pogrešne i štetne akcije ${ }^{{ }_{77}}$. U nastavku je izrazio slaganje sa stavovima Saveza komunista Hrvatske i Srbije, „druga Tita i sa stavovima svih onih koji u tim aktima vide nedopustivu metodu delovanja i štetnu i opasnu političku

72 „Prilagođavanje Ustava društvenom razvitku“, Borba, god. XXXII., br. 81., 25. ožujka 1967., str. 4.

73 Isto.

74 Isto.

75 „Šire uključivanje republika i utvrđivanje politike zajednice“, Politika, god. LXIV., br. 19206., 25. ožujka 1967., str. 5.

76 „Izbor delegacije za Veće naroda-suvereno pravo svake republike“, Borba, god. XXXII., br. 85., 28. ožujka 1967., str. 5. 
diverziju“"77. Deklaracija je sigurno imala odraza i na međuljudske odnose jer su se preko noći na različitim stranama našli stari poznanici i prijatelji. O novonastalim prilikama Štambuk kaže:

Prvi put u poslednjih trideset godina, razilazim [se] sa nekim svojim starim drugovima i prijateljima, saborcima od kojih neki predstavljaju značajna imena savremene hrvatske književnosti i kulture. Ja bih, svakako, bio mnogo srećniji da do toga nije došlo i znam da će me radi svega, proglasiti unitaristom, kao što su to učinili sa drugom Žankom. Ja nisam unitarista, kao ni drug Žanko, a osećam deklaraciju i rezoluciju upravo sa stanovišta suprotnog unitarističkom, sa stanovišta pravih interesa hrvatskog naroda, sa stanovišta bratstva i jedinstva naših naroda, bez kojega nema ni socijalističke budućnosti, ni nezavisnosti hrvatskog naroda ni integralnosti njegove nacionalne kulture. (...) Živeći u Beogradu, mnogonacionalnom centru naše zemlje, $u$ kojemu nikada nisam osetio ni najmanji pritisak na moju narodnu pripadnost, ni na moj hrvatski jezik i aktivnost kao pisca i novinara, ni na svoj politički integritet, ja nisam pao pod uticaj jedne malograđansko-provincijske šovinističke histerije koja, na žalost, vlada u redovima jednog dela zagrebačkih intelektualaca ${ }^{78}$.

Na kraju je Štambuk odbacio i tvrdnje da se u Armiju uvodi jedan jezik, tj. srpski jezik, što predstavlja „težak greh protiv Partije i protiv Armije, protiv nas samih koji smo to sve stvarali i koji sve to nosimo" ${ }^{\text {"9 }}$. Iako je u diskusijama ove sjednice sudjelovalo više govornika, nitko od njih nije izravno spominjao Deklaraciju ${ }^{80}$.

Privredno i Socijalno-zdravstveno vijeće Savezne skupštine održali su svoje sjednice 28. ožujka 1967. godine. Na sjednici Socijalno-zdravstvenoga vijeća posebno je široku raspravu u sklopu rasprave o Deklaraciji imao dr. Ivan Lalić koji je naveo da je narod Hrvatske Deklaraciju shvatio kao političku diverziju, da je bilo zadovoljstvo pratiti reakciju

\footnotetext{
Isto.

78 Isto.

79 Isto.

8o Politika kao diskutante spominje Džemala Bijedića, Dragišu Ivanovića, Kolu Čašulea, Radojku Katić, Martina Dudu, Milenka Kangraga, Ružicu Miliković, Veljka Zekovića, Milorada Vučković, Petra Rihtera i Tihomira Rankovića. Vidi „Još dva veća podržala ustavne promene“, Politika, god. LXIV., br. 19209., 28. ožujka 1967., str. 5.
} 
radnih ljudi u Hrvatskoj te da su idejni začetnici Deklaracije pravili račun bez krčmara. U nastavku je naveo da su tvorci Deklaracije vjerovali da će

kao samozvani zaštitnici hrvatskih interesa, uz pomoć „deklaracije“, oko sebe okupiti hrvatski narod. Deklaracija im se, međutim, povratila poput bumeranga. Hrvatski narod im je odgovorio dostojanstveno i trezveno, ali $u$ isto vreme odlučno i energično. Umesto da izazovu razdor između srpskog i hrvatskog naroda, nosioci „deklaracije“ su, može se slobodno reći, otvorili neformalni plebiscit, kroz koji se tačno videlo ko uz koga stoji i šta ko želi. Na jednoj strani okupila se ogromna većina radnih masa, koja teži ka socijalizmu i progresu, dok se s druge strane oko „deklaracije" počela okupljati šačica nacionalista, šovinista, okorelih birokrata i svih mogućih reakcionara, koji bi hteli da zaustave točak istorije ${ }^{81}$.

Neki su pozivali i na odgovornost potpisnika, među kojima i Lalić koji je za potpisnike Deklaracije naveo da „kriju svoja imena kao zmija noge i da je vreme da u obračunu s njima budemo konkretni i otvoreni i da se radnom čoveku kaže ko su ti ljudi i čije interese predstavljaju“" ${ }^{\text {" }}$. Tiskovine su prenijele i pitanje Paška Romca: „Naša javnost je upoznata s 'deklaracijom' i beogradskom 'porukom' u vezi s napadom na nacionalno jedinstvo naših naroda. Potpisnici su, međutim, ostali anonimni. Ljudi se pitaju: ako je to borba protiv jedinstva, ako je to izraz šovinističkih i nacionalističkih tendencija, zašto su potpisnici ostali u anonimnosti? ${ }^{\text {"83 }}$. Odgovor je na navedeno pitanje dostavljen na narednoj sjednici Privrednoga, Organizaciono-političkoga i Socijalno-zdravstvenoga vijeća Savezne skupštine 14. travnja 1967. godine. U odgovoru tajnik Skupštine Dražen Sesardić navodi da je Matica hrvatska uputila Skupštini pismo koje su potpisali predsjednik Jakša Ravlić i tajnik Igor Zidić. U prilogu pisma bio je tekst Deklaracije. „Sam tekst 'Deklaracije' nije potpisan, već se na kraju navode samo ustanove koje su je podnele. U tekstu

81 „Ustavne promene podržane u privrednom i socijalno-zdravstvenom veću“, Politika, god. LXIV., br. 19210., 29. ožujka 1967., str. 5.

82 Isto. Borba je također pratila rad navedene sjednice. Vidi „Oštrica 'Deklaracije' okrenula se protiv njenih inicijatora", Borba, god. XXXII., br. 85., 29. ožujka 1967., str. 5.

${ }_{3}$ "Odgovori na poslanička pitanja-Zašto su potpisnici 'deklaracije' ostali anonimni“, Politika, god. LXIV., br. 19210., 29. ožujka 1967., str. 5. 
'Deklaracije' nema oznake imena, niti potpisa lica koja su u ime pojedinih ustanova podržale 'Deklaraciju'. Nema ni podataka na osnovu kojih bi se mogao dati odgovor zašto imena pojedinih potpisnika 'Deklaracije' nisu navedena," ${ }^{84} \mathrm{a} \mathrm{u}$ "pogledu potpisnika takozvanog 'Predloga za razmišljanje', koji je u celoj jugoslovenskoj javnosti naišao na osudu, kao i sama 'Deklaracija', ne bih mogao dati odgovor jer 'Predlog' nije primljen u Saveznoj skuštini“ ${ }^{485}$. Spomenuti je tajnik Skupštine Sesardić već ranije, i to 7. travnja 1967. godine, na sjednici Saveznoga vijeća odgovarao na slično zastupničko pitanje Ivice Momčinovića o tome je li Deklaracija upućena Saveznoj skupštini i što je po tome poduzeto. U Sesardićevu se odgovoru navodi da je Matica hrvatska tekst Deklaracije dostavila Saveznoj skupštini i Veljku Vlahoviću, predsjedniku Komisije Saveznoga vijeća za izradu teksta ustavnih amandmana. Sesardić je dalje naveo da su s Deklaracijom bili upoznati svi članovi Predsjedništva Skupštine koji su na posebnoj sjednici zaključili da se ne udovolji Matičinoj predstavci. O navedenome stavu obaviještena je Matica pismom u kojem stoji:

„Deklaracija o nazivu i položaju hrvatskog književnog jezika“, koju ste dostavili vašom predstavkom br. 252/47 od 15. marta 1967. godine, naišla je, kao što je poznato, na široku, spontanu i oštru osudu u Socijalističkoj Republici Hrvatskoj i celoj jugoslovenskoj javnosti, koja je „Deklaraciju“ primila kao napad na bratstvo i jedinstvo naroda Jugoslavije, dragocenu tekovinu narodnooslobodilačke borbe, socijalističke revolucije i socijalističke izgradnje naše zemlje. I Predsedništvo Savezne skupštine pridružilo se ovoj osudi „Deklaracije“. Predsedništvo Skupštine je konstatovalo da su isti stav prema „Deklaraciji“ izneli i svi poslanici koji su o njoj govorili u skupštinskim telima. Nijedan savezni poslanik nije, dakle, u Skupštini podržao stavove „Deklaracije“, niti u smislu odredaba Poslovnika podneo predlog koji se u njoj iznosi. Ovim se obaveštavate da zbog svega toga Predsedništvo Savezne skupštine nije moglo udovoljiti zahtevu vaše predstavke da se predlozi iz „Deklaracije“ uzmu u razmatranje u postupku izmena Ustava koje se sada pripremaju ${ }^{86}$.

${ }_{84}$ „Zašto su potpisnici 'Deklaracije' i 'Predloga' ostali anonimni“, Politika, god. LXIV., br. 19227., 15. travnja 1967., str. 7.

${ }^{8}$ „'Deklaracija' je dostavljena Skupštini bez potpisa“, Borba, god. XXXII., br. 103., 15. travnja 1967., str. 4.

86 „Predlozi iz 'Deklaracije’ nisu uzeti u razmatranje“, Politika, god. LXIV., br. 19220., 8. travnja 1967., str. 5. 
Na plenumu Centralnoga vijeća Saveza sindikata Jugoslavije 10. travnja 1967. godine Deklaracija i Predlog ocijenjeni su kao „politička diverzija malog broja kulturnih i prosvetnih radnika" ${ }^{87}$, a na sjednici Saveznoga izvršnoga vijeća 12. travnja usvojena je informacija „o pitanju doslednije i efikasnije primene ustavnih načela o ravnopravnosti jezika i pisma naroda Jugoslavije ${ }^{\text {“88. }}$.

\section{Kažnjavanje potpisnika}

Stavovi su republičkih i saveznih vijeća ubrzo počeli utjecati na život i rad potpisnika koji su, pored stegovnih mjera izbacivanja iz Saveza komunista, pismenih ukora i drugih oblika verbalnih kazni, ubrzo osjetili i konkretnije oblike kažnjavanja i stigmatiziranja. Slavko Pavešić i Miroslav Šicel povukli su se s kandidacijske liste za odbornike Prosvjetno-kulturnoga vijeća zagrebačke Gradske skupštine. Pavešiću se predbacivalo da je bio član Komisije koja je sačinila tekst Deklaracije, a Šicelu da je Deklaraciju potpisao u ime svoga kolektiva. ${ }^{89} \mathrm{O}$ navedenim je ostavkama obaviještena Izborna komisija Gradskoga odbora SSRN Zagreba 6. travnja 1967. godine. Na zajedničkoj sjednici Prosvjetno-kulturnoga vijeća Skupštine Zagreba i Savjeta za kulturu grada 11. travnja 1967. godine prihvaćena je ostavka dotadašnjega predsjednika zagrebačkoga Prosvjetno-kulturnog vijeća dr. Ive Frangeša. Prisutnim je pročitano pismo ostavke u kojem je Frangeš naveo da je kao potpisnik Deklaracije kažnjen isključenjem iz Saveza komunista Jugoslavije te da je ta činjenica nespojiva s njegovim daljnjim ostankom na položaju predsjednika vijeća. ${ }^{\circ 0}$ Profesor Ekonomskoga fakulteta Ivan Vrančić povukao je kandidaturu za zastupnika u Prosvjetno-kulturnome vijeću

87 „Dušan Petrović-Šane novi predsednik Centralnog veća“, Politika, god. LXIV., br. 19223., 11. travnja 1967., str. 5 .

88 „Radne organizacije izbegavaju da prime mlade stručnjake“, Politika, god. LXIV., br. 19225., 13. travnja 1967., str. 5 .

89 Vidi „Trojica potpisnika Deklaracije povukla kandidature“, Borba, god. XXXII., br. 95., 7. travnja 1967., str. 6.

90 Usp. „Usvojena ostavaka dr Ive Frangeša“, Borba, god. XXXII., br. 10o., 12. travnja 1967., str. 4; „Predsednik Prosvetno-kulturnog veća Gradske skupštine Zagreba dr Ivo Frangeš podneo ostavku“, Politika, god. LXIV., br. 19224., 12. travnja 1967., str. 6. 
Savezna skupštine. O navedenoj je ostavci obaviještena Izborna komisija Gradskoga odbora SSRN Zagreba 6. travnja 1967. godine. Vrančiću se predbacivalo da je sudjelovao na proširenoj sjednici Upravnoga odbora Matice hrvatske kada je Deklaracija prihvaćena. ${ }^{91}$ Neka su kažnjavanja inicirala službena tijela. Savjet za naučni rad Hrvatske 14. travnja 1967., sukladno zaključcima Prosvjetno-kulturnoga vijeća Sabora SR Hrvatske o utvrđivanju stupnja odgovornosti inicijatora i potpisnika Deklaracije, ispitivao je pojedinačnu odgovornost svojih članova, te je u vezi s tim prihvatio ostavku člana Savjeta dr. Ive Frangeša, člana Odbora za društveno-humanističke nauke dr. Ljudevita Jonkea te člana Komisije za izdavačku djelatnost dr. Rudolfa Filipovića. ${ }^{92}$

\section{Prosvjedi, javna očitovanja i otvorena pisma neformalnih grupa i pojedinaca}

Pored partijskih, republičkih i državnih organa o Deklaraciji su iznošeni stavovi na radničkim prosvjedima, javnim očitovanjima i otvorenim pismima neformalnih grupa i pojedinaca. Politika je pisala o prosvjedima 23. ožujka oko pet tisuća radnika Rade Končara protiv stavova iznesenih u Deklaraciji. Pored navedenoga prosvjeda Borba piše i o prosvjedima radnika u Rijeci, Slavonskoj Požegi, Sesvetskom Kraljevcu, Zlataru, Jankomiru i Borongaju. Među poduzećima čiji su radnici prosvjedovali spominju se Rade Končar, Elka, Radioindustrija Zagreb, Me-Ba, Nikola Tesla, Gataldus, Prvomajska, OKI, Lip-mil, Industrija za elektroniku, Janko Gredelj, Jugoton, Pliva i Aleksandar Mamić. Na prosvjedu Rade Končara okupljenim radnicima tajnik tvorničkoga komiteta SK Jere Perkov pročitao je pismo u kojem se navodi da su radni ljudi

neugodno iznenađeni Deklaracijom, da ona nije potekla od radnih ljudi i ne izražava njihove težnje. - U nastojanjima za daljom afirmacijom samoupravljanja mi se susrećemo sa integracijama preduzeća na među-

${ }_{91}$ Vidi „Trojica potpisnika 'Deklaracije’ povukla kandidature“, Borba, god. XXXII., br. 95., 7. travnja 1967., str. 6.

92 Vidi „Savet je uvek financirao naučne radove o jeziku na osnovi novosadskog dogovora“, Politika, god. LXIV., br. 19227., 15. travnja 1967., str. 8. 
republičkom i na međudržavnom planu, brišući tako granice republika i država, a da nam pri tome ne predstavljaju problem jezici kojima izražavamo naše zajedničke interese. Nametanje iskonstruisanih problema protivreči našim interesima, posebno interesima najmlađe generacije odgojene u duhu bratstva i jedinstva ${ }^{93}$.

Prosvjedi radnika spominju se i u Borbinu komentaru Jednodušnost. ${ }^{94}$ Politika je 26. ožujka izvijestila o skupovima u Rijeci na kojima je osuđena „deklaracija o nazivu i položaju hrvatskog književnog jezika i zatraženo da njeni inicijatori snose odgovarajuće političke posledice ${ }^{\text {“95. }}$.

Čitav se niz Matičinih ogranaka uključio u osudu Deklaracije. Politi$k a$ i Borba izravno su pisale samo o reakcijama u Rijeci i Splitu, a dok se u nekim drugim člancima usputno spominju reakcije i u nekim drugim ograncima. ${ }^{96} \mathrm{Za}$ riječki se Upravni odbor pododbora Matice hrvatske navodi da "niko od članova pododbora nije učestvovao niti je bio kon-

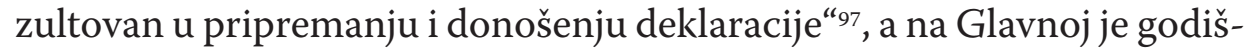
njoj skupštini Matice hrvatske u Splitu 17. travnja 1967. prihvaćen tekst osude Deklaracije, uz navođenje da nitko od članova Matice hrvatske iz

93 „Deklaracija ne izražava težnje radnih ljudi“, Borba, god. XXXII., br. 81., 25. ožujka . 1967., str. 6.

94 Pored spominjanja poduzeća u članku se donose citati iz nekoliko pisama koja su pristigla različitim novinskim redakcijama. Vidi „Jednodušnost“, Borba, god. XXXII., br. 81., 25. ožujka 1967., str. 1-2.

95 „Društvene organizacije i naučne ustanove Rijeke osuđuju 'deklaraciju', Politika, god. LXIV., br. 19207.,26. ožujka 1967., str. 8.

96 Navedene se osude usputno spominju i u članku u Politici „Kako je nastala Deklaracija“. Autor navedenoga članka problematizira zašto se o Deklaraciji nije raspravljalo u svim ograncima Matice hrvatske uz puno sudjelovanje njezinih članova i javnosti. Podsjeća da Matica ima 21 ogranak u Hrvatskoj u kojima ima nekoliko tisuća članova. Autor se poziva na izjave ogranaka iz Dubrovnika, Rijeke, Siska, Osijeka i drugih mjesta koje su objavljene u tisku, a u kojima ogranci navode da nisu bili konzultirani niti su sudjelovali u izradi i donošenju Deklaracije. Vidi „Kako je nastala Deklaracija“, Politika, god. LXIV., br. 19214., 2. travnja 1967., str. 7-8. Da Matičini ogranci nisu bili konzultirani, potvrđuje i Berislav Jandrić. Vidi „Pogledi na Deklaraciju o nazivu i položaju hrvatskog književnog jezika“, Povijesni prilozi, god. XVIII. (1999.) br. 18., str. 329.

97 „Društvene organizacije i naučne ustanove Rijeke osuđuju 'deklaraciju“", Politika, god. LXIV., br. 19207.,26. ožujka 1967., str. 8. 
Splita nije sudjelovao u pripremi Deklaracije niti je potpisao navedeni dokument..$^{98}$ Deklaraciju je osudio i

komitet visokoškolskih ustanova i fakulteta Rijeke, grupa od 250 riječkih prosvetnih radnika, učesnici zajedničkih sednica, Opštinskih komiteta Saveza komunista i Opštinskog sindikalnog veća Rijeke i proširene sednice Sekretarijata Sreskog komiteta Saveza komunista"99. Protestu protiv Deklaracije priključio se i riječki Novi list čiji su djelatnici potpisnicima Deklaracije uputili otvoreno pismo u kojem navode da Deklaraciju smatraju „otvorenom političkom diverzijom na jedinstvo naših naroda, nacionalističkim ispadom i atakom na najsvetiju tekovinu naše socijalističke revolucije, za koju je palo milijon i 7oo hiljada života. (...) U pismu se dalje kaže da nametanje jezika kao 'gorućeg problema' u ovom trenutku predstavlja opasan pokušaj odvraćanja pažnje javnosti od suštinskih pitanja socijalizma ${ }^{100}$.

Nastavnici Filozofskoga fakulteta u Sarajevu obratili su se otvorenim pismom javnosti 28. ožujka 1967. U pismu navode: „dubokim žaljenjem smo primili 'Deklaraciju' i 'Predlog za razmišljanje', kao akte koji u odnose između naroda i narodnosti na srpskohrvatskom (hrvatskosrpskom) jezičnom području, posebno u Bosni i Hercegovini, mogu unijeti elemente nerazumijevanja i razdvajanja, koji zadiru u bit odnosa naroda ne samo hrvatskosrpskog (srpskohrvatskog) jezičkog područja nego i cjelokupne jugoslovenske socijalističke zajednice ${ }^{{ }^{101}}$. Borba je 5 . travnja prenijela priopćenje Upravnoga odbora i Predsjedništva Udruženja univerzitetskih nastavnika i naučnih radnika BiH koji su se pridružili osudi Deklaracije i Predloga. U njihovu se priopćenju ističe da

univerzitetski nastavnici i svi naučni radnici vrlo dobro znaju kolika je njihova odgovornost u jačanju i afirmaciji jugoslovenske zajednice naroda i jugoslovenskog socijalitčkog društva. Otuda članovi Udruženja -

98 Vidi „Matica hrvatska u Splitu osudila 'Deklaraciju“, Politika, god. LXIV., br. 19230., 18. travnja 1967., str. 9.

99 „Društvene organizacije i naučne ustanove Rijeke osuđuju 'deklaraciju'“, Politika, god. LXIV., br. 19207., 26. ožujka 1967., str. 8.

100 „Protest kolektiva riječkog 'Novog lista'“, Politika, god. LXIV., br. 19208., 27. ožujka 1967., str. 7.

101 „Izvesni intelektualci žele da podignu zid između hrvatskog i srpskog naroda“, Politika, god. LXIV., br. 19210., 29. ožujka 1967., str. 6. 
pedagozi, naučnici i politički radnici - ne mogu a da ne osete koliko je za Bosnu i Hercegovinu i za celu Jugoslaviju štetan stav iznet u 'Deklaraciji' i 'Predlogu'. Neprincipijelno i nametljivo nastojanje da se pobije naučna istina o jedinstvu hrvatskog i srpskog jezika i zahtev za proglašavanjem njihove razdvojenosti u suštini predstavlja svesno suprostavljanje bratstvu i jedinstvu kao najvećoj tekovini zajedničke borbe i revolucije naših naroda $^{102}$.

O Deklaraciji se očitovalo i Društvo novinara Hrvatske na svojoj godišnjoj skupštini 7. travnja 1967. godine. Uz osudu Deklaracije oni su ,jednodušno istakli da je novinarstvo u Hrvatskoj uvek bilo u prvim redovima borbe za socijalističke principe i pobornik bratstva i ravnopravnih odnosa jugoslovenskih naroda i nacionalnosti i"${ }^{{ }_{103}}$. Skupština je također odlučila da se o odgovornosti književnika, članova Društva novinara, njih osam, koji su sudjelovali u donošenju Deklaracije, „nezavisno od one u drugim organizacijama, raspravi Sud časti Društva novinara Hrvatske “104. Pitanjem ravnopravnosti jezika bavio se izvanredni kongres Saveza novinara Jugoslavije s kojega je izviješteno da će djelokrug njihova rada između ostalog biti i „zastupanje interesa jugoslavenskog novinarstva u inostranstvu i u doslednom ostvarivanju ravnopravnosti jezika naših naroda u poslovanju i u službenom glasilu“" ${ }^{105}$.

Stavovi različitih neformalnih grupa i pojedinaca iznošeni su u Borbinoj rubrici „Pisma uredništvu“ ${ }^{106}$ Posebno su bili aktivni u pisanju

${ }_{102}$ „Deklaracija' - pobijanje naučne istine o jedinstvu hrvatskog i srpskog jezika“, Borba, god. XXXII., br. 92., 5. travnja 1967., str. 4.

${ }_{103}$ „Doprinos novinarstva društvenim kretanjima“, Borba, god. XXXII., br. 96., 8. travnja 1967., str. 6.

104 Isto.

105 „Vanredni kongres Saveza novinara Jugoslavije održaće se 12. maja u Splitu“, Politika, god. LXIV., br. 19225., 13. travnja 1967., str. 5.

106 U uvodu se spomenute rubrike 24. ožujka 1967. navodi da redakciji u posljednjih nekoliko dana „stižu mnogobrojna pisma čitalaca iz svih krajeva zemlje sa jednodušnom osudom Deklaracije o nazivu i položaju hrvatskog knjižebnog jezika." „Pisma uredništvu“, Borba, god. XXXII., br. 8o., 24. ožujka 1967., str. 2. I u Vjesniku je postojala slična rubrika koja je objavljivala „priloge čitatelja, pravih i izmišljenih, u kojima se napada Deklaracija i osuđuju njezini potpisnici." J. PAvičıć, Deklaracija..., str. 24. Berislav Jandrić navodi da je na stotine pisama upućeno redakcijama dnevnih listova, a da su Centralni i Izvršni komitet SK Hrvatske tijekom dva tjedna primili 210 raznih protestnih pisma, telegrama i dopisa. („Pogledi na Deklaraciju...., str. 333). Pisama podrške bilo je dosta manje. Uglavnom je riječ o anonimnim 
pripadnici JNA. U pismu se profesora u jednoj armijskoj školi u Zagrebu S. Reljića ${ }^{107}$ navodi da u JNA ,jezična praksa nije crna kao što se u deklaraciji ističe (...) u JNA niko namerno i svesno ne sprovodi jezički unitarizam $^{{ }_{108}}$. On priznaje da se u JNA koristi pretežno ekavica i latinično pismo, ali tomu

nije kriva namera i svest već objektivni život i rad u Armiji. U JNA nikome ne smeta postojeće jezičko stanje (što ne znači da ga ne treba na razborit i koristan način unapređivati). Niko se ne osjeća nacionalno ugroženim: svi pripadnici Armije mogu se slobodno i privatno i službeno služiti bili kojom varijantom hrvatskosrpskog jezika. Još nikome ni na kraj pameti nije bilo da me ukori ili barem upozori što u vojnoj školi predajem na hrvatskoj varijanti hrvatskosrpskog jezika. (...) Želeo bih da potpisnici Deklaracije opovrgnu taj svoj dokument, koji verujem, neće ući u svetle stranice istorije hrvatske kulture ${ }^{109}$.

Svakako je među pripadnicima JNA, koji su se javno očitovali o Deklaraciji, najzvučnije ime generala pukovnika Viktora Bubanja. ${ }^{110}$ On u svome pismu ističe da se nitko u njegovu cjelokupnom radu nije interesirao zašto piše hrvatskom varijantom srpskohrvatskoga jezika te ukazuje na odredbe članka 42. Ustava po kojemu je službeni jezik u JNA srpskohrvatski, što nitko nikada nije "shvatio kao zahtjev da se piše samo srpskim jezikom. (...) U JNA se ustvari najviše piše i govori jednim zajedničkim mješanim jezikom, jer nas je to naučila praksa i službovanje širom SFRJ. Prema tome u JNA ne postoji uopšte problem

pismima. (Isto, str. 336). I NIN je donio nekoliko pojedinačnih reakcija na aktualne jezične rasprave. Vidi „Nacionalistička a ne jezička razmišljanja“, Nin, br. 847., 2. travnja 1967., str. 8.

${ }_{107}$ Riječ je o Stevi Reljiću. Njegovo je pismo objavio i armijski časopis Front 23. ožujka 1967. godine. Sadržaj pisma iz Borbe i Fonta različit je. Usp. M. Samadžıja, Deklaracija... str. 286. - 290 i „U Armiji niko ne sprovodi jezički unitarizam“, Borba, god. XXXII., br. 79., 23. ožujka 1967., str. 2.

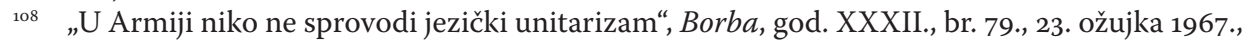
str. 2.

109 Isto.

110 Viktor Bubanj (1918-1972) „hrv. general; službovao u Jugoslavenskoj narodnoj armiji (JNA). Na visokim zapovjednim položajima u antifaš. ratu (1941-45), potom u ratnom zrakoplovstvu. God. 1970-72. načelnik Generalštaba JNA." <enciklopedija.lzmk.hr/clanak. aspx?id $=4853>$, (4. II. 2020.). 
nepriznavanja srpskohrvatskog ili hrvatskosrpskog jezika" ${ }^{111}$. U pismu spominje i zakinutost zapovjednika iz Slovenije i Makedonije koji su svjesni da je uporaba srpskohrvatskoga uvjetovana specifičnosti JNA i da to „ne znači nikakvo nepriznavanje njihove nacionalnosti i jezika, već isključivo da je to jedna nužnost tehničkog karaktera zbog specifičnosti JNA, načinom njenog dejstva u ratu zbog čega je potreban jedinstven jezik, terminologija i komande ${ }^{{ } 112}$. Potpukovnik Rade Petrović iz Zagreba kaže da potpisnici Deklaracije kritiziraju jedinstveni jezik u diplomaciji i JNA, „a zaboravljaju da u našoj zemlji nema sredine, preduzeća ni ustanove gde nema ljudi raznih nacionalnosti. Pitam autore kakav onda to jezik treba da bude u selima Banije, Korduna, Like, Slavonije i drugih

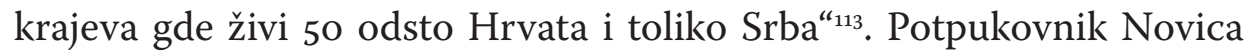
Savić iz Zemuna piše „kažite nam što pre ko su kreatori 'Deklaracije o hrvatskom književnom jeziku' i potpisnici 'Predloga za razmišljanje’ u Beogradu. I jedni i drugi zaslužuju najoštriju osudu“"14, a major Jovan Bačić iz Ćuprije „pridružujem se osudi nacionalističkih i šovinističkih ispada. Zajednička borba nas je ujedinila i treba nemilosrdno uklanjati sve ono što bi nas razdvojilo“"15. Pukovnik Stanko Štetić iz Beograda navodi da radi u izdavačkoj djelatnosti JNA i da 95 \% djela tiskaju na latinici, a „njihova jezička redakcija izvršena je uz strogo poštovanje želje autora i usvojenih pravila hrvatskosrpskog (srpskohrvatskog književnog jezika) ${ }^{{ }^{116}}$. General potpukovnik Milan Žeželj ${ }^{117}$ iz Beograda navodi da je zaprepašten „drskim i neuračunljivim poduhvatom potpisnika Deklaracije - ljudi od kojih se očekuje da doprinesu kreiranju naše kulture i umetosti, a ne da miniraju naš ponos, našu današnjicu i naše sutra. (...)

${ }^{111}$ „U JNA nikome ne smeta sadašnja jezička praksa“, Borba, god. XXXII., br. 81., 25. ožujka 1967. str. 2.

112 Isto.

${ }_{113}$ „Široka osuda ataka na jedinstvo“, Borba, god. XXXII., br. 80., 24. ožujka 1967., str. 2.

${ }_{114}$ „Široka osuda ataka na jedinstvo“, Borba, god. XXXII., br. 82., 26. ožujka 1967., str. 2.

115 Isto.

116 „Široka osuda ataka na jedinstvo“, Borba, god. XXXII., br. 83., 27. ožujka 1967., str. 2..

${ }_{117}$ Milan Žeželj (1917-1995) sudionik rata od 1941. Bio je „na dužnosti, pored ostalog, zamjenika zapovjednika I. proleterskog bataljona Hrvatske, zamjenika zapovjednika pa zapovjednika 13. proleterske brigade i gardijske brigade. Poslije rata zapovjednik Garde JNA, zatim načelnik štaba graničnih jedinica. Narodni heroj". <https://peoplepill.com/people/milan-zezelj/> (4. II. 202O.). 
Deklaracija je atak na bratstvo i jedinstvo. Javnost je oštro osudila njene potpisnike, čija bi imena trebalo objaviti što pre ${ }^{{ }_{118}}$. Major Aćim Bakrač iz Sarajeva navodi da je Deklaracija „pokušaj stavljanja klipova u točkove našeg brzog voza koji juri ka progresu. Srećom, točkovi idu tako brzo da ih ni ovaj pokušaj neće zaustaviti. Ipak, 'zaštitnici hrvatskog jezika' za ovakav pokušaj treba da odgovaraju“"119. Poručnik korvete Josip Kljaković iz Pule piše: „Član sam Matice hrvatske, pogođen sam Deklaracijom koja je napisana i u moje ime i u ime mojih drugova. Bili smo iznenađeni i grubo isprovocirani vašom Deklaracijom, gospodo potpisnici. Ovo nije pomoć da se rešavaju razni problemi u jednoj višenacionalnoj državi, već nešto suprotno od toga“"120.

Čitav je niz i drugih pojedinačnih reakcija običnih građana. Riječanin Rudol Lukin-Doko izražava čuđenje pojavom Deklaracije i pita se

čiji je to jezik ugrožen i od koga? Mi, obični građani, koji nismo književnici ni lingvisti ni naučni radnici, ne rukovodimo naučnim kulturnim organizacijama ne patimo mnogo od toga, i nismo, ubeđeni da je hrvatski (ili pak nečiji drugi jezik) doveden u neravnopravni položaj. Ali nas veoma zabrinjava činjenica da toliko godina posle završetka oružane borbe postaje pomalo „moderno“ da se diže prašina oko ugroženosti nečijeg jezika. ${ }^{121}$

Ljubo Mraović iz Zagreba smatra da u donošenju Deklaracije „nije bilo dovoljno dobrih namera. Ovo ne može da ne izazove osudu javnosti. Očigledno je da se ne radi o zaštiti hrvatskog jezika, jer je pitanje priznanja ovog jezika zagarantovano našim Ustavom. To je politička deklaracija, a ne deklaracija o zaštiti hrvatskog jezika" ${ }^{\text {"122 }}$. Potpisnicima posebno zamjera onaj dio Deklaracije koji govori o potrebi da nastavnici i javni radnici, bez obzira na to otkuda potjecali, koriste jezik sredine u kojoj djeluju. Mraović ukazuje da u Hrvatskoj žive Hrvati i Srbi te

\footnotetext{
${ }_{118}$ „Jednodušnost u osudi Deklaracije i Predloga za razmišljanje“, Borba, god. XXXII., br. 87., 31. ožujka 1967., str. 2.

119 Isto.

120 Isto.

${ }^{121}$ „Čiji je jezik ugrožen i od koga?" Borba, god. XXXII., br. 78., 22. ožujka 1967., str. 2.

${ }_{122}$ „Politička a ne jezička akcija?" Borba, god. XXXII., br. 78., 22. ožujka 1967., str. 2.
} 
da "nema slobode i ravnopravnosti hrvatskog naroda u Jugoslaviji bez

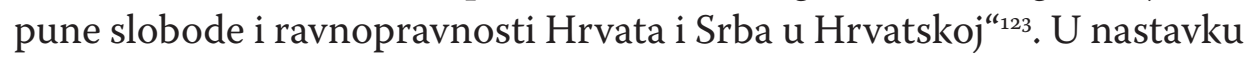
izražava slaganje sa sadržajem članka Zvonke Radoša "Juriš na otvorena vrata“ te predlaže da se "na merodavnom mestu naše društvo ogradi od ovakvih deklaracija, jer one ne služe podizanju međunacionalnih odnosa na viši nivo već postaju hrana šovinističkim i antisocijalističkim elementima ${ }^{{ }^{124}}$. Ante Križanić iz Zagreba navodi da ne treba nikako dozvoliti podvajanje jezika, a Deklaracija to traži, ,jer je to opasno zatvaranje u nacionalne okvire umesto da se ide suprotno, da se još više radi na zbližavanju naroda“" ${ }^{\text {"125. }}$. Mirko Raonić i Andrija Vuković iz Beograda u svome pismu postavljaju pitanje tko su potpisnici Deklaracije te traže od redakcije Borbe "da u jednom od narednih brojeva objavi imena potpisnika". ${ }^{126}$ Marko Todorović iz Skoplja kaže da mu nije jasno što se Deklaracijom traži, jer to što se traži, već je riješeno Ustavom. Nikola Piljak iz Beograda također traži objavljivanje imena potpisnika, a Veljko Grba iz Zemuna izražava nevjericu „da danas, 117 godina posle sastanka uglednih hrvatskih i srpskih književnika i naučnih radnika u Beču neko može kod nas da postavlja pitanje razdvajanja srpskohrvatskog odnosno hrvatskosrpskog jezika“" ${ }^{{ }_{127}}$. Savo Sekulović iz Subotice razumije „jezik saradnje, jezik Vladimira Nazora, Ivana Gorana Kovačića, Gaja, Šenoe, Branka Radičevića, Koste Racina, Prešerna, ali ne i jezik potpisnika 'deklaracije', jezik niskih strasti i pobuda“" ${ }^{\text {"128. }}$. Tonči Jakšić iz Bograda ukazuje da je napad na bratstvo i jedinstvo kazneno djelo „i za to se po našim zakonima krivično odgovara. Samo deklarativna osuda nije dovoljna ${ }^{{ }^{129} \text {, }}$ a studentica Jagoda Jakovčev iz Beograda odbacuje postojanje ugroženosti bilo kojega jezika. ${ }^{130}$ Beograđanin Mile Žakula postavlja pitanja komu smetaju jezične razlike, a Milorad Čukić „ko ima pravo da govori

\footnotetext{
123 Isto.

124 Isto.

${ }_{125}$ „Široka osuda ataka na jedinstvo“, Borba, god. XXXII., br. 8o., 24. ožujka 1967., str. 2.

126 Isto.

127 Isto.

128 Isto.

129 „Široka osuda ataka na jedinstvo“, Borba, god. XXXII., br. 82., 26. ožujka 1967., str. 2.

${ }_{130}$ Vidi isto.
} 
u ime 20 milijona Jugoslovena, sem Saveza komunista" ${ }^{\text {"131 }}$. Miroslav Durgovac iz Skoplja poziva na skidanje rukavica "nek se zna koji su to ljudi i koji pisci“" ${ }^{132}$. U kontekstu rasprava o Deklaraciji student Milan Polić iz Zagreba traži da se omogući izjašnjavanje kao Jugoslaven - „mi se mladi samo takvima osećamo i dozvolite da se tako i zovemo ${ }^{{ }^{133} \text {. Branko }}$ Petrić iz Ličkoga Petrovog Sela izražava svoje slaganje s pisanjima Miloša Žanka i Ferde Čulinovića ${ }^{134}$ te podsjeća da su autori „zaboravili da u Hrvatskoj, pored Hrvata, žive i Srbi, Slovenci, Crnogorci i drugi, govore

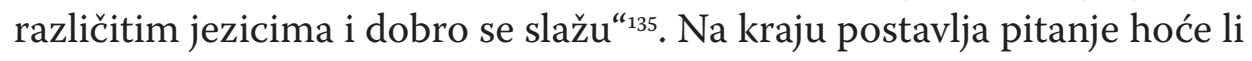
netko odgovarati za pokušaj vrijeđanja bratstva i jedinstva. Andrija Bartovčak iz Bjelovara postavlja pitanje ima li među potpisnicima „učesnika naše revolucije? Ako ima, zar su posle 22 godine pobede nad fašizmom zaboravili na 1,7 miliona žrtava“"136.

Neka su pisma slale skupine građana organiziranih prema različitim osnovama. Građani su Splita iz Ulice Maksima Gorkoga, njih 93, problematizirali uporabu atributa hrvatski u nazivu jezika te postavili pitanje što to hrvatski jezik gubi ako nema atribut hrvatski. ${ }^{137} \mathrm{U}$ pismu se Radničkoga savjeta Radne organizacije „Aleksandar Mamić“ iz Rijeke navodi: „ogorčeni smo na deklaraciju grupe zagrebačkih naučnika i književnika. Dosta je tolerancije prema onima koji čine bilo šta da naruše bratstvo i jedinstvo. U našoj radnoj organizaciji ima nas iz svih krajeva Jugoslavije, pripadnika svih naroda i narodnosti. Nikome od nas ne pada na pamet da jedan drugome zameramo kako ko govori ili pi$\check{s}^{{ }^{{ }^{\prime}}{ }^{138}}$. U pismu se Radnoga kolektiva „Tekstilstroj“ iz Zagreba navodi da u njihovoj „radnoj organizaciji ima ljudi koji govore štokavski, ekavski,

\footnotetext{
${ }_{131}$ „Široka osuda ataka na jedinstvo“, Borba, god. XXXII., br. 83., 27. ožujka 1967., str.2

${ }_{132}$ Isto.

${ }^{133}$ „Jednodušnost u osudi Deklaracije i Predloga za razmišljanje“, Borba, god. XXXII., br. 87., 31. ožujka 1967., str. 2.

${ }^{134}$ Ovdje se vjerojatno misli na stavove koje je Ferdo Čulinović iznio u članku „Kuda idemo?“, Borba, god. XXXII., br. 77., 21. ožujka 1967., str. 4.

${ }^{135}$ „Jednodušnost u osudi Deklaracije i Predloga za razmišljanje“, Borba, god. XXXII., br. 87., 31. ožujka 1967., str. 2.

136 Isto.

${ }_{137}$ Usp. „Široka osuda ataka na jedinstvo“, Borba, god. XXXII., br. 8o., 24. ožujka 1967., str. 2.

${ }_{138}$ „Široka osuda ataka na jedinstvo“, Borba, god. XXXII., br. 82., 26. ožujka 1967., str. 2.
} 
ijekavski, kajkavski i čakavski. To nikome ne smeta, odlično se sporazumevamo. Dajemo punu podršku stavovima i zaključcima Izvršnog komiteta SKH Gradskog komiteta SK i Glavnog odbora SSRN Hrvatske.

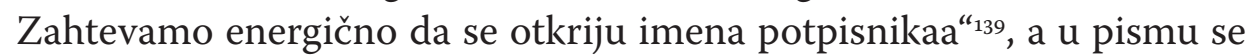
Gradskoga omladinskoga vijeća Zagreba poziva „sindikalne podružnice i organe samoupravljanja u institucijama u čije je ime Deklaracija doneta, da ispitaju sve okolnosti pod kojima je izvršeno potpisivanje De-

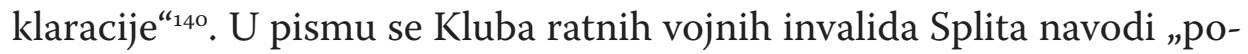
treseni smo i ogorčeni pojavom Deklaracije - pokušajem da taj otrovni pamflet pomuti bratstvo i jedinstvo naših naroda ${ }^{\text {"141 }}$, a u pismu sudionika Mjesne konferencije UROPA Pula da „bratstvo i jedinstvo osnovna

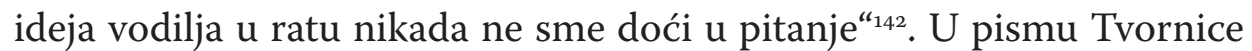
čokolade, bombona i keksa "Josip Kraš“ iz Zagreba navodi se da pojava Deklaracije predstavlja napad na bratstvo i jedinstvo te poručuju „potpisnicima Deklaracije da se ne poigravaju s bratstvom i jedinstvom i ne preuzimaju ulogu koja im ne pripada". ${ }^{143}$ Kolektiv Građevinskoga poduzeća „Novotehna“ iz Karlovca piše „nauka je oduvek služila za dobro čoveka, stvarala mostove, objedinjavala ljude i svoje sokove crpila iz naroda. Ovi naši 'naučnici' čine suprotno. Koliko slabo poznaju našu stvarnost!“. ${ }^{144} \mathrm{U}$ pismu se grupe prosvjetnih radnika iz Splita navodi da Deklaracija

svojom sadržinom i duhom neobično podseća na proklamaciju ustaške 'lingvističke», nazovi naučne 'teze' iz 1941. kada su 'jezička pitanja' u praksi rešavana brojnim koljačkim jamama, logorima u Gradiški, Jasenovcu, Lepoglavi, pokoljem u glinskoj crkvi itd. Zato je ton Deklaracije u nama izazvao ogorčenje, jezu, gnev. Zbog toga je potrebno što pre objaviti imena potpisnika i objaviti detaljna objašnjenja o tome kako je Deklaracija stvorena ${ }^{145}$.

139 „Jednodušnost u osudi Deklaracije i Predloga za razmišljanje“, Borba, god. XXXII., br. 87., 31. ožujka 1967., str. 2.

140 Isto.

${ }^{141}$ Isto.

142 Isto.

143 Isto.

144 Isto.

145 Isto. 
U pismu članova Sindikalne podružnice Radničkoga univerziteta „Jurica Kalc“ i Kulturno-prosvjetne zajednice Pula traži se „političku odgovornost autora, a posebno članova SK u tim ustanovama. Osuđujemo i autore Rezolucije grupe Udruženja književnika Srbije čije su idejne i političke pozicije antisocijalističke ${ }^{{ }_{146}}$. U rubrici "Pisma uredništvu“ objavljivana su pisma skupina organiziranih na partijskoj osnovi. ${ }^{147}$

\section{Zaključak}

O Deklaraciji su republička i savezna tijela raspravljala manjim intenzitetom nego partijske strukture. Rasprave su vođene samo u hrvatskim saborskim i jugoslavenskim saveznim skupštinskim vijećima. Skupštine drugih republika o Deklaraciji nisu raspravljale. Navedeno je i razumljivo jer je Deklaracija dostavljena samo vijećima nadležnim za promjenu ustava, tj. Saboru SR Hrvatske i Saveznoj skupštini. U neku ruku može biti čudno zašto Skupština SR Srbije nije zauzela stav o Pred$\operatorname{logu}$ za razmišljanje, pogotovu što je o njemu opširno raspravljao beogradski gradski komitet SK i CK SK Srbije. O Deklaraciji su se u $\mathrm{Hr}-$ vatskoj očitovala sva saborska vijeća, a rasprave su vođene i u nekim drugim tijelima. Posebno je zanimljivo da su o Deklaraciji raspravljala i vijeća koja nisu imala bliže formalne nadležnosti nad pitanjima koje pokreće jer je zakone i akte donosilo Republičko vijeće „ravnopravno s onim vijećem Sabora iz područja čije nadležnosti se konkretni zakon ili druga akt donosi ${ }^{{ }^{\prime 148}}$. Sukladno navedenomu bliže veze s problematikom koju je Deklaracija pokrenula imalo je samo Prosvjetno-kulturno vijeće. Način funkcioniranja tadašnjega sustava najbolje se očituje u činjenici da su o Deklaraciji, koja je dostavljena Saboru, a ne CK SK Hrvatske, saborska vijeća počela raspravljati prilično kasno, odnosno tek nakon što

\footnotetext{
146 Isto.

${ }_{147}$ Riječ je o pismima Osnovne organizacije Saveza komunista Sekretarijata za privredu SRH i građana mjesne organizacije SSRN Varoš u Splitu.Vidi „Široka osuda ataka na jedinstvo“, Borba, god. XXXII., br. 80., 24. ožujka 1967., str. 2., „Jednodušnost u osudi Deklaracije i Predloga za razmišljanje“, Borba, god. XXXII., br. 87., 31. ožujka 1967., str. 2.

${ }_{148}$ Sumarni inventar - Sabor Socijalističke republike Hrvatske 1945-1982, izradio: Nenad Bukvić, Hrvatski državni arhiv, Zagreb, 2012, str. 12.
} 
su se o njoj nedvosmisleno izjasnili partijski forumi. Očito se čekao stav partijskih organa, što upućuje na to da su saborska i savezna vijeća bila produžene ruke Saveza komunista čiji su se stavovi morali bespogovorno i bez bilo kakvih ideoloških zastranjivanja slijediti. Saborska su vijeća donijela čitav niz zaključaka, a svi bi se oni mogli sažeti u nekoliko rečenica. Potpisnicima se Deklaracije zamjeralo rušenje bratstva i jedinstva, narušavanje odnosa između hrvatskoga i srpskoga naroda i osporavanje jedinstva hrvatskoga i srpskoga jezika. Zbog toga se u raspravama i zaključcima pozivalo na utvrđivanje odgovornosti, kazneno procesuiranje te skidanje s rukovodećih pozicija i kandidacijskih lista za različita saborska i savezna skupštinska tijela. Pored saborskih i skupštinskih vijeća o Deklaraciji se pisalo, raspravljalo i protiv nje prosvjedovalo na cjelokupnome jugoslavenskom prostoru. Kvalifikacije iznesene u otvorenim pismima u duhu su onoga što je govoreno na partijskim forumima, saborskim i saveznim vijećima. Posebno je vidljiva angažiranost pripadnika JNA u osudi Deklaracije, a u neku ruku čude osude koje su dolazile iz Matičinih ogranaka. Osim u saborskim i skupštinskim vijećima, izvanpartijske su reakcije na Deklaraciju zabilježene samo u $\mathrm{BiH}$, i to nastavnika Filozofskoga fakulteta u Sarajevu i Upravnoga odbora i Predsjedništva Udruženja univerzitetskih nastavnika i naučnih radnika $\mathrm{BiH}$. U pojedinim se raspravama, zaključcima i pozivima za utvrđivanje odgovornosti u istu ravan stavljaju potpisnici Deklaracije i sastavljači Predloga za razmišljanje.

Usporede li se stavovi izvanpartijskih tijela, neformalnih grupa i pojedinca sa stavovima partijskih foruma, postaje vidljivo da u retorici i pristupu problemu nema bitne razlike. Čak je retorika nekih saborskih vijeća, grupa i pojedinaca radikalnija od retorike partijskih foruma. $\mathrm{Na}$ vedeno se posebno odnosi na istup Jure Galića, ali i na pismo skupine građana iz Splita koji su pojavu Deklaracije dovodili u vezu s ustašama i zločinima počinjenima u Drugome svjetskom ratu. Očito se cjelokupni život tadašnjega društva promatrao kroz prizmu i stavove partijskih središta, što ukazuje na potpunu ideološku indoktriniranost društva od najviših državnih razina do običnih ljudi i radnika zaposlenih u ondašnjim poduzećima. Kada se sagledaju stvarne posljedice izvanpartijskih 
rasprava i osuda, one nisu bile velike. Javni tužitelj nije nikomu dokazao kaznenu odgovornost, a kazne su se svele na podnošenje ostavki i skidanje s kandidacijskih lista za neka vijeća. 


\section{REACTIONS OUTSIDE THE PARTY AND DISCUSSIONS ON DECLARATION ON THE NAME AND STATUS OF THE CROATIAN LITERARY LANGUAGE ACCORDING TO POLITIKA AND BORBA}

\section{Abstract}

Appearance of the Declaration on the Name and Status of the Croatian Literary Language was followed by discussions and disapprovals of its signatories. Besides disapprovals coming from the city, republic and federal Party centers, there were also those from different Croatian republic and Yugoslav federal bodies. Serbian newspapers were extensively reporting from the meetings of the Republic Council, Economic Council, Social and Health Council, Organizational and Political Council and Education and Culture Council of the Parliament of the SR Croatia as well as Education and Culture Council, Economic Council, Social and Health Council and Federal Council of the Federal Parliament. Declaration was also discussed by some other republican and federal bodies: Republic Chamber of Commerce, Croatian Scientific Council, Committee of the Federal Council for Socio-Economic Relations and Central Council of the Yugoslav Trade Union Confederation. Some bodies outside the Party in $\mathrm{B} \& \mathrm{H}$ also presented their comments on the Declaration. Those are the teachers of the Faculty of Philosophy in Sarajevo and Management Board and Presidency of the Association of University Teachers and Scientists of B\&H. Serbian newspapers also devoted much of their media space to reactions of individuals and informal groups. They were giving their comments on the Declaration mostly through open letters. 
All the above mentioned bodies evaluated the Declaration in the similar way to the Party views. They declared it as an attack to brotherhood and unity, defended the unity of Croatian and Serbian language, invited to determining the responsibility of the signatories. Because of being included into adoption of the Declaration some signatories resigned from their posts and candidate lists for certain republic and federal councils.

Keywords: Declaration on the Name and Status of the Croatian Literary Language; Croatian parliament and Yugoslav federal councils; ideological discussions on language; reactions of individuals and informal groups; punishing of the Declaration signatories 